Boston University School of Law

Scholarly Commons at Boston University School of Law

Faculty Scholarship

2009

\title{
American Moment[s]: When, How, and Why Did Israeli Law Faculties Come to Resemble Elite U.S. Law Schools?
}

Pnina Lahav

Boston University School of Law

Follow this and additional works at: https://scholarship.law.bu.edu/faculty_scholarship

Part of the Legal Education Commons

\section{Recommended Citation}

Pnina Lahav, American Moment[s]: When, How, and Why Did Israeli Law Faculties Come to Resemble Elite U.S. Law Schools?, 10 Theoretical Inquiries in Law 653 (2009).

Available at: https://scholarship.law.bu.edu/faculty_scholarship/579

This Article is brought to you for free and open access by Scholarly Commons at Boston University School of Law. It has been accepted for inclusion in Faculty Scholarship by an authorized administrator of Scholarly Commons at Boston University School of Law. For more information, please contact lawlessa@bu.edu. 


\title{
BU School of Law
}

\section{AMERICAN MOMENT[S]: WHEN, HOW, AND WHY DID ISRAELI LAW FACULTIES COME TO RESEMBLE ELITE U.S. LAW SCHOOLS?}

\author{
Boston University School of Law Working Paper No. 09-32
}

(July 29, 2009)

Pnina Lahav

This paper can be downloaded without charge at:

http://www.bu.edu/law/faculty/scholarship/workingpapers/2009.html 


\title{
Theoretical Inquiries in Law
}

Volume 10, Number 2

July 2009

Article 13

HistoriEs OF LEGAL TRANSPLANTATIONS

\section{American Moment[s]: When, How, and Why Did Israeli Law Faculties Come to Resemble Elite U.S. Law Schools?}

\author{
Pnina Lahav*
}

Copyright (c)2009 The Berkeley Electronic Press. All rights reserved. 


\title{
American Moment[s]: When, How, and Why Did Israeli Law Faculties Come to Resemble Elite U.S. Law Schools?
}

\begin{abstract}
Pnina Lahav ${ }^{*}$
Following independence in 1948, the Hebrew University of Jerusalem founded a law faculty and modeled it on the European example (Continental and British). Today, the Israeli law faculty is much more similar to the U.S. law school than to institutions of legal education in Europe. This Article traces the history of the changes in Israeli legal education. It argues that the shift began after 1967, faced resistance in the 1980s, and gained momentum in the 1990s. Presently we may be witnessing the beginning of a shift away from U.S. influence and back to Continental Europe or even Asia. The Article discusses three major educational components, which together signaled the shift to U.S. influence: a student-run law review, curricular reform, and open and lively class discussion. The Article then offers several factors to explain the shift: judicial opinions that began to rely on American
\end{abstract}

* Boston University School of Law. This Article was written during my fellowship with the Institute for Advanced Studies at the Hebrew University of Jerusalem and I wish to express my gratitude to the IAS and its staff for their gracious hospitality. I also wish to thank members of the Legal History workshop at Tel Aviv University, members of the workshop at the Faculty of Law of the Netanya College, members of the workshop at Boston University School of Law, and members of my research group at the Institute for Advanced Studies at the Hebrew University for valuable comments and suggestions. I also wish to thank Olga Frishman for her research assistance, and Ron Harris, Assaf Likhovski, Roy Kreitner, Leora Bilsky, Dafna Hacker, Sandy Kedar, Celia Wasserstein-Fassberg, Daphne Barak-Erez, Laura Kalman, David Sugarman, Yifat Gazit Holzman, Ori Shwartz, and Gail Hupper for their specific comments. The responsibility for the contents of this Article is mine alone. 
decisional law, the adoption of the U.S. model of practice by the legal profession, the privatization of law schools, globalization, and Americanization and foreign affairs. Finally, the Article considers the contribution to Americanization made by active U.S. attempts to export American law to other legal systems.

\section{Preface}

Open the sleek website of the Faculty of Law at Tel Aviv University and you will find beside the faculty's motto, "Training the future leaders of the legal community," a link to its "Executive LL.M. program in commercial law in cooperation with the University of California at Berkeley, Boalt Hall

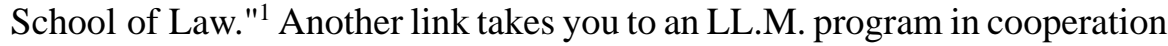
with Northwestern University's Law School, where the instructors are "top professors" from both the Tel Aviv and the Northwestern law schools, and the degree is bestowed by both institutions. The LL.B. program at Tel Aviv lists a wide variety of concentrated courses, taught in English by American professors who come to Tel Aviv expressly for this purpose. for example, in the spring of 2008 a student could take up to twelve different concentrated courses, eleven of which were taught in English. Among the instructors are such illustrious professors as Alan Schwartz of Yale, William Forbath of the University of Texas in Austin, Gregory Alexander of the Cornell Law School, Ruti Teitel of the New York Law School, and Lynn Cohen of the Northwestern Law School. Of the twelve, ten come from the United States. ${ }^{2}$ Five of the twelve are Israelis who are currently members of U.S. law faculties, and these are no less illustrious. Among them are Hadar Aviram of the University of California at Hastings, Yochai Benkler of the Harvard Law School, Oren Bracha of the University of Texas in Austin, Meir Dan-Cohen of the University of California at Berkeley, and Andrei Marmor of the University of Southern California Law School. ${ }^{3}$

1 Tel Aviv University, The Buchmann Faculty of Law, http://www.law.tau.ac.il (last visited June 10, 2008). The program consists of three semesters, with the third semester (in the summer) taking place at Berkeley with courses "taught in English, by ... [Boalt] professors who specialize in business law."

2 The two outstanding are Arie Freiberg of Monash University in Australia, and Kurt Siehr of the Max Planck Institute in Hamburg. They may symbolically represent the historic influence on Israeli law of the British Commonwealth and Germany, respectively.

3 At the Hebrew University of Jerusalem, the semester of spring 2008 has seven visitors from abroad teaching intensive courses in English: Marshall Brieger, Catholic 
Clearly, the collaboration between Israel and the United States is rather intense. American professors and the American model of legal education are embedded in the Israeli legal landscape. ${ }^{4}$ The American visitors to Israel's law schools no longer fantasize Israel as a faraway exotic land peppered with smiling kibbutzniks and women soldiers brandishing Uzis. Today, Israel is a space which culturally and professionally is not very different from the United States. ${ }^{5}$ When one thinks of similarities and dissimilarities between the United States and Israel, one generally considers the academic product scholarship. Israeli scholarship today is quite similar to American scholarship - little black-letter law and a lot of law and economics, feminism, cultural analysis, legal history and other "law and ..." work. This Article assumes a relationship between legal scholarship and legal education, and posits that the main building blocks of legal education, modeled after the United States, have played an important role in conditioning young scholars to connect and remain connected to American legal thought, in all its variety. In what follows, I shall try to explore the intellectual origins of this development and suggest a few factors which have affected and enhanced the process of Americanization.

University, Washington DC; Jeffrey Rachlinksy, Cornell Law School; Phillipe Sands, University College of London; Suzanne Last Stone, Cardozo Law School; Mark Tushnet, Harvard Law School; and Tom Ulen, College of Law, University of Illinois. A seventh visitor is Judge Gerald Rosen of the District Court for the Eastern District of Michigan. The pattern observed in the text is repeated: most of the professors come from the United States. In addition to these two law schools, Haifa University and Bar-Ilan University also have law schools. To these one should add six private law schools established primarily in the Tel Aviv area, all founded since the 1990s. All law faculties engage in the practice of inviting foreign professors to give intensive courses in English.

4 Law and economics in particular, a field which presumably is more immune to social sensibilities, has flourished in Israel, perhaps because one of the leaders of the field, Harvard Law professor Lucian Bebchuk, is also an Israeli and a member of the Tel Aviv Faculty of Law. Oren Gazal-Ayal argues that the number of Israelis working in this field is disproportionally high. See Oren Gazal-Ayal, Comments On The Past And Future Of the Economic Analysis Of Law In Israel, 23 MECHKEREY MishPAT 661 (2007) (Hebrew); and Oren Gazal-Ayal, Economic Analysis of Law in North America, Europe and Israel, 3 REV. L. \& ECON. 485 (2007). It should be emphasized, however, that Israelis excel in the academic environment of the United States in fields other than law and economics. Notable examples are Meir Dan-Cohen, Yochai Benkler, Andrei Marmor, Ayelet Shachar, and Ran Hirschl.

5 Similarly, whereas through the mid-1970s Israel held few international conferences and could not attract the best and the brightest from the U.S. to attend, today there are scores of such conferences, studded with star law professors in every field. Many, but by no means all, of the visiting professors to the Israeli law schools are Jewish. This is another interesting angle awaiting further research. 


\section{Periodization: The History OF AMERICAN INFLUENCE ON ISRAELI LEGAL EDUCATION}

Today, Israeli law faculties bear many similarities to their U.S. counterparts. ${ }^{6}$ This has not always been the case. Shifting our gaze twenty years backwards to 1982, we find a short article by then Dean Joshua Weisman of the Hebrew University Faculty of Law titled On the Teaching of Law in the United States and in Israel. ${ }^{7}$ In his article, Dean Weisman issued a warning that "the exposure of law professors in Israel to the conventional methods of legal education in American law schools carries the risk that the teacher who returns to Israel will teach what he has learnt and not what students should study." ${ }^{8}$ Let me dwell briefly on this statement. Weisman, an eminent scholar of property law, was not discussing visiting professors, and plainly could not anticipate the Israeli network of law professors presently expanding in the United States. ${ }^{9}$ Weisman was addressing a simple exercise in transplantation: Israeli graduates who studied in the U.S., returned to Israel, and enthusiastically imported the American method. In 1982, Dean Weisman smelled a problem: the American teaching method. It was sufficiently big a problem to be detected already, yet appeared to be sufficiently small to justify an expectation that it could be nipped in the bud. I shall return to the methods Dean Weisman rejected, and those he endorsed, momentarily, but for now all I wish to record is the moment of open resistance. By the early 1980s, something was happening to the Israeli law school, which was disturbing to some of its leaders. Many disapproved of the American influence and warned that it was unfit for Israel.

6 For an analysis of Israeli academic emigration to the United States (in all fields), see Dan Ben-David, Brain Drained (CEPR Discussion Paper No. 6717, 2008), available at http://papers.ssrn.com/sol3/papers.cfm?abstract_id=1141623.

7 Joshua Weisman, On the Teaching of Law in the United States and in Israel, 12 MishPATIM 425 (1982) (Hebrew) [hereinafter Weisman, On the Teaching of Law]. The article was first published in English as part of a symposium on legal education conducted at the Tel Aviv Faculty of Law. Joshua Weisman, The Relevance of the American Experience to Legal Education in Israel, 5 TEL AvIV STUD. L. 55 (1980-1982) [hereinafter Weisman, The Relevance of the American Experience].

8 Weisman, On the Teaching of Law, supra note 7.

9 In Givat Ram, the law school building was located behind the national library and opposite the buildings of the science faculties, thereby perhaps signaling the aspiration to conceptualize law as a science rather than an art. On Mount Scopus, the law school is adjacent to the social sciences buildings. The home of the Tel Aviv Faculty of Law is located between the social sciences and the humanities buildings. 
Think backwards to the fall of 1967, fifteen years before Weisman delivered his warning. The spring and summer of that year witnessed the war that changed the face of Israel. In all probability, the Six Day War had something to do with our story, albeit through subtle and sometimes unseen channels. ${ }^{10}$

But this comes later. In the academic year 1966/1967, two Israeli law professors from the Hebrew University, Aharon Barak and Itzhak Zamir, ${ }^{11}$ spent a year as visiting scholars at Harvard. Barak, then 30 years old, had completed his Ph.D. under Gad Tedeschi at the Hebrew University. Zamir, then 36 years old, had completed his Ph.D. at the University of London. At Harvard Law School, the two friends took, among other courses, the groundbreaking course on legal process, and another course on American legal education. Both courses were etched in their minds. The legal process course, taught by Henry M. Hart, Jr. and Albert M. Sacks, introduced the two to another way of thinking about the law, a way that deeply influenced their future scholarship. ${ }^{12}$ David Cavers' course on legal education introduced them to the components of legal education reviewed below, as well as to the significance of interdisciplinary study for legal thought. ${ }^{13}$

10 One change may be mentioned immediately - the faculty of law of the Hebrew University, located in the Givat Ram campus, spearheaded the relocation of the campus to Mount Scopus, as Israel reasserted its sovereignty over the mountain and celebrated the reunification of its capital. See Mordechai Kremnizer, From the Peak of Mount Scopus, 2 MishPatim 3 (1970) (Hebrew) ("the faculty of law ascended the mountain .... [A] project of renovation and the joy accompanying it"). The growing interest and pride of U.S. Jewry in Israeli affairs after 1967 resulted in handsome contributions, which facilitated academic meetings and encouraged interest in the Israeli legal academic enterprise.

11 In 1975, after a year as dean, Barak was appointed Attorney General in Rabin's (first) government. His decision to indict Rabin's wife for illegally holding a bank account in the U.S. led to Rabin's resignation. However, Barak did share Rabin's admiration for the American political system and culture. In 1978, Barak was appointed to the Supreme Court, and in 2006 retired as its chief justice. See Nomi LEVITZKI, Kvodo (2001) (Hebrew). Zamir followed Barak to the deanship, and later served as Attorney General in Menachem Begin's government. He too was appointed to the Supreme Court, and served between 1994 and 2001.

12 In the early 1970s, together with Ruth Gavison, Barak and Zamir taught the legal process course at the Hebrew University. For the impact of legal process thought on Israeli scholarship, see PNina Lahav, Judgment in Jerusalem: ChiEf Justice Simon AGRANAT AND THE ZiONIST CENTURY (1995).

13 I could not locate Cavers' syllabus at Harvard Law School. His ideas are captured in his scholarship. See, e.g., Remarks by David F. Cavers to Duke Students Concerning the Origin of and Vision for Law and Contemporary Problems, 51 LAW \& CONTEMP. PROBS., at xxiii (1988). 
On their return to Jerusalem, the two initiated reforms in legal education in keeping with the American model which they had witnessed at Harvard. I suggest that this was the American moment. Seeds of American influence were planted on Israel's legal soil. The implantation, however, did not proceed smoothly, and yet despite skepticism and resistance, these seeds survived. The close interaction between American and Israeli legal education can and should be traced to 1967.

I am suggesting four dates along a continuum: 1967 - beginnings; 1982 - resistance; 1990s - invigoration and acceleration; and 2008 augmentation and peak. ${ }^{14}$ These dates constitute a rough periodization of the process of rising American influence over Israeli legal education. I should also add the conventional caveat: nothing happened overnight. This has been a slow process consisting of small, incremental steps. Only in hindsight do these dates assume any critical significance. ${ }^{15}$

Nor is it the case that American legal education was transplanted wholesale into Israeli law. A great deal about Israeli legal education is authentic and specific to Israel, and surely English and continental European influence have been particularly strong. In addition, I am looking at structural changes. I only too briefly touch below on American influence on Israeli legal thought in my discussion of teaching styles. Clearly, there is a relationship between legal education and scholarship, but a thorough exploration is beyond the framework of this Article. ${ }^{16}$ Finally, three notes. First, many persons were involved in this process from its beginnings, and their support as well as resistance shaped the outcome. These persons were acting in the context of a major transformation of Israeli society, a transformation in which our subject

14 Daphne Barak-Erez suggests that there were in fact two American moments. She thinks the major shift in legal education, particularly at the Tel Aviv Faculty of Law, occurred in the 1990s, and should be recognized as an independent "American Moment" rather than as a continuation of the process launched in the early 1970s. I confess to uncertainty as to whether this is a quantitative or qualitative difference, but I am comfortable with two, over one, American moments.

15 I do not carefully trace independent developments in each of these institutions, but point rather to major developments which occurred in one or the other. In the beginning Jerusalem served as a model, which Tel Aviv sought both to emulate and deviate from in order to emphasize its separate identity. This Article is based mainly on printed articles and interviews, and includes some, but far from thorough, study of internal protocols. Again, a more intensive study of the documents awaits another paper.

16 For an interesting analysis of the various schools of legal thought, which includes documentation of the Israeli contribution within each school, see Gad Barzilai, The King Is Not Naked - Why Law Is Political, 4 Din U-Dvarim 1 (2008) (Hebrew). 
matter - legal education - is only a footnote. I apologize to all who are not mentioned here. Second, I am only discussing the first two law faculties in Israel, which to this day are considered leaders of the pack. But there are other law schools in Israel, and each is developing its own concept of legal education. Their contribution, too, will have to await further investigation. ${ }^{17}$ Third, the picture appears in clarity now at exactly the moment when Israelis may begin to note a shift — the budding of an old-new romance with continental Europe, especially with Germany, and perhaps the beginning of a relationship with law schools in Asia.

Certainly, American influence over Israel's legal system did not begin in the late 1960s. ${ }^{18}$ As Assaf Likhovksi has shown, a program of collaboration between Israel and Harvard Law School began as early as $1950 .{ }^{19}$ Moreover, prominent members of the Israeli legal community obtained their legal education in the United States. For example, Chief Justice Simon Agranat graduated from the University of Chicago Law School in 1928, just before embarking on a boat to Palestine. Agranat served as professor of criminal law at the Faculty of Law in Jerusalem from the early 1950s to the mid-1960s, and his approach to criminal law bore the marks of his American legal education. ${ }^{20}$

17 See supra note 3 for a list of law schools.

18 There has been an American presence in Israeli higher education from the very beginnings of the Hebrew University of Jerusalem in the 1920s. See, e.g., Walter Ackerman, The Americanization of Israeli Education, 5 IsR. STUD. 228, 235 (2000) (reviewing the influence of John Dewey's work on Israeli educators, and stating that "several generations of curriculum workers and students in Israel have been taught a conception of curriculum - and, by extension, of teaching and other aspects of schooling - which is peculiarly American"). Similarly, the Department of Economics at the Hebrew University had a strong American presence since the late 1940s, due primarily, but not exclusively, to the fact that Don Patinkin, a graduate of the University of Chicago, was its energetic and influential dean. See Nachum Gross, 'Economics' at the Hebrew University Before the 'Patinkin Age' (Maurice Falk Inst. for Econ. Research in Isr., Discussion Paper No. 00.05, 2000) [hereinafter Gross, Economics Before Patinkin]; and Nachum Gross, The Department of Economics at the Hebrew University During the 1950s (Maurice Falk Inst. for Econ. Research in Isr., Discussion Paper No. 04.06, 2006). I thank Ephraim Kleiman for directing me to these materials.

19 See Assaf Likhovski, Argonauts of the Eastern Mediterranean: Legal Transplants and Signaling, 10 TheORETICAL InQuires L. 619 (2009). Also, in 1958, an International Lawyers Convention was held in Israel, and Harvard Law professor David Cavers was a guest of honor. $I d$. at 641 .

20 He taught scores of students, including Barak and Zamir. LAHAV, supra note 12. Another example is Justice Shneur Zalman Cheshin, a founding father of Israel's Supreme Court, who received his law degree at N.Y.U. Law School. 
His canonical opinion in the case of Kol Ha'am wove U.S. First Amendment doctrine into Israeli law. ${ }^{21}$ Three Israelis received their S.J.D. at Harvard Law School during the 1950s: Avigdor Levontin in 1954, and Yehezkel Dror and Theodor Meron in 1957. All three went on to have formidable academic careers, but only Levontin tied his lot with the Faculty of Law at Hebrew University, served as dean, and taught several courses there, including an introductory course to the English legal system and conflict of laws. ${ }^{22}$ During the 1960s, Yale Law School produced four Israeli graduates: Yuval Levy and Amos Shapira, who joined the Faculty of Law at Tel Aviv, and Michael W. Reisman and Arie David, who remained in the United States. ${ }^{23}$ Somehow this distinguished group did not turn the ship of Israeli legal education toward American shores. Evidently, conditions were not ripe for such a development.

Meanwhile, the late 1960s saw not only the return of Barak and Zamir from Harvard Law School, but also the establishment of a second law school at Tel Aviv University. Until 1966/67, the Tel Aviv Faculty of Law was formally a "branch" of the Hebrew University Faculty of Law, and many of

21 HCJ 73/53 Kol Ha-Am v. Minister of the Interior (1953) 7 IsrSC 871 (Hebrew), 1 Selected Judgments Sup. Ct. Isr. 90 (1948-1953) (English). See also Pnina Lahav, American Influence on Israel's Jurisprudence of Free Speech, 9 HASTINGS CONST. L.Q. 21 (1981).

22 Levontin also spent a year teaching at Yale Law School. Theodor Meron, who also had a degree from Cambridge, England, returned in 1957 to serve in the Israeli Ministry of Foreign Affairs, and since 1975 has been a professor of international law at N.Y.U. Law School. More recently, he served as president of the international criminal tribunal for the former Yugoslavia. Yehesqel Dror, whose thesis at Harvard Law School addressed "Law as a Policy Making Instrument," returned in 1957 to join the faculty of political science at the Hebrew University, and became an internationally known expert in policy studies. In the early 1960s, two Israeli students, Daniel Friedmann and Ami Ben-Porat, took their LL.M. at Harvard Law School. Friedmann returned to Israel and pursued his $\mathrm{Ph} . \mathrm{D}$. at the Hebrew University. He became the second dean of the Tel Aviv Faculty of Law, and was Minister of Justice in the Olmert cabinet, leading the campaign to roll back the jurisprudence that Barak developed from the bench.

23 "I was an uncritical fan," Shapira remembered in an interview. Shapira obtained his S.J.D. from Yale Law School, working with Ronald Dworkin, Guido Calabresi, and Leon Lipson. Earlier, Shapira received an MCL (Master in Comparative Law) from the School of Law at Columbia University, and on his return never tired of informing everyone about the "way we do things at Columbia." Interview with Amos Shapira in Tel Aviv (Apr. 13, 2008). Michael Riesman joined the Yale Law School Faculty. Arie David was a member of the faculty of law at the Hebrew University, but decided to return to the United States. Yuval Levy founded a prosperous law firm in Tel Aviv, but continued teaching. 
its teachers were members of the faculty at Hebrew University. ${ }^{24}$ By now the independent faculty was ready to make its mark, and one way it was hoping to do so was through educational reforms. The inspiration for these reforms was sought in the United States. Thus the reforms in both law faculties mirrored and trailed each other. ${ }^{25}$ Competition between the two schools was helpful in enhancing reform, and in hindsight the effects of Americanization are not the same in both schools. Again, this matter must await another paper.

Three major reforms beginning at the end of the 1960s signaled what I call "the American moment": the establishment of a student-run law review, curricular reform, and the introduction of a different teaching method, based primarily on more lively class discussion, which often culminated in an open-book exam. To these one should add clinical programs, moot courts, and workshops, all important educational tools that trace the American model, but which I shall not discuss. ${ }^{26}$

What I call the American moment is primarily the time when these ideas were consciously put on the table. Some of the suggestions for reform, such as the establishment of a student-run law review, were relatively easily accepted. Others encountered substantial resistance. At the end, it does appear that the American moment heralded a new era for Israeli law

24 The current building serving as a home to the faculty was the first on the Tel Aviv Campus. Originally it was home to the Higher School for Law and Economics in Tel Aviv, which was closed down to give way to the "branch." See Assaf Likhovski, Legal Education in Mandatory Palestine, 25 IYUNEY MISHPAT 291 (2001) (Hebrew).

25 My introduction opens with a description of Tel Aviv University's Faculty of Law in the text, and a parallel description of the Faculty of Law at the Hebrew University in a footnote. Both law faculties were influenced by the United States. However, it is my impression that Tel Aviv was more receptive to American influence, and that the Hebrew University has experienced more resistance. This matter calls for further investigation. It could be that Barak and Zamir's retirement from the faculty during the 1970s (both served as attorney general, and thereafter as justices of the Supreme Court) left a vacuum, which empowered the resistance to American influence at that institution. Similarly, when Tel Aviv's first dean, Amnon Rubinstein, retired to pursue a political career, inertia may have settled in, which accounts for the view that the significant "American moment" occurred in the 1990s.

26 Olga Frishman, Curricular Trends in Law Schools - The Case of Tel Aviv University (2007) (unpublished seminar paper, Tel Aviv University, on file with author) (Hebrew). This seminar paper is based on Faculty protocols and is recommended for a study of the period. I thank Ron Harris for bringing this paper to my attention, and Ms. Frishman for sharing it with me. For a good discussion of the clinical programs, see Neta Ziv, Combining Professionalism, Nation Building and Public Service: The Professional Project of the Israeli Bar, 1928-2002, 71 FORDHAM L. REV. 1621 (2003). 
schools. After reviewing these reforms, I shall suggest some factors which spurred and facilitated their integration.

\section{A. Law Reviews as Educational Tools: Mishpatim and Iyuney Mishpat}

Until 1968, the Israeli legal community had two law reviews: Ha-Praklit, and the Israel Law Review. Ha-Praklit ("The Attorney"), established in 1943, was the journal of the Israeli Bar Association and was run by attorneys. It published in Hebrew primarily short pieces on doctrinal issues. ${ }^{27}$ The Israel Law Review, established at the Hebrew University in 1966, appeared in English and was more ambitious academically. It aimed to showcase Israeli scholarship to the world, and to give Israeli scholars the opportunity to publish in English, and thereby meet the requirements of publication for purposes of promotion within the university. ${ }^{28}$ It was run by senior members of the faculty at the Hebrew University, was peer-reviewed, and was assisted by a professional editorial staff. Students were not involved with either journal.

In 1968, the Faculty of Law at the Hebrew University decided to establish a new law review that would be run by students. They called it Mishpatim. This was a major step, signaling (to use Assaf Likhovski's theory ${ }^{29}$ ) that there is, or should be, enough legal scholarship to justify a second Hebrew venue, that legal education and scholarship went hand in hand, that good students were or should be an integral part of the educational and scholarly enterprise, and, last but not least, that the Faculty of Law at the Hebrew University was aspiring to resemble the model of excellence embodied by Harvard Law School. ${ }^{30}$

27 Ha-Praklit is now run by the students of the Faculty of Law of the Administrative College in Rishon Le-Zion under the supervision of a faculty member. Prior to 1948, there were several attempts to publish legal journals in Palestine.

28 There was very little interest in Israeli law outside of Israel throughout the 1950s and 1960s, and the likelihood that a U.S. or UK law review would be interested in publishing scholarship about it was quite low. Because Israeli scholars were required to publish in English for purposes of promotion, they felt obliged to publish either comparative pieces (also not too popular at the time), or scholarship related to American law or the common law. It could also be that Israelis were not sufficiently known in the U.S. to impress the editorial boards of U.S. law reviews. Note that the decision was made to publish the Israel Law Review in English, not in French or German. This, despite the fact that it has been said that Israeli law was influenced by European Law, and that many of its founders had European legal training.

29 See Likhovski, supra note 19.

30 In his Foreword to the first issue, Dean Reuven Yaron stated that the main purpose of Mishpatim was "to serve as an important educational tool, first and foremost to the best students who are its editors, and beyond them to the many who will use it 
Indeed, in form Mishpatim did resemble the Harvard Law Review. In an interview, Barak remembered visiting the editorial board of the Harvard Law Review at Gannett House, studying their modus operandi, and consulting their bylaws. On his return to Israel, he proposed adopting the same model. The idea of a student-run law review was not easily swallowed by the faculty. Some faculty members were skeptical about the ability of students to make serious editorial decisions, and probably were puzzled by the wisdom of submitting their scholarship to the judgment of students. Joshua Weisman, a young professor who followed Barak and Zamir as a visiting scholar at Harvard Law School, felt strongly that the American model was misguided. Weisman was not against a law review, but thought that editing was a professional skill which law students did not possess. Furthermore, in his view, any accumulated professional experience would disappear as old editors were replaced by new. Interviewed in 2008, he felt even more confident that the professional scholar's interaction with the student editors had enough drawbacks to trump the pedagogic advantages. ${ }^{31}$

In 1968, however, Barak applied his formidable persuasive skills and the law review was launched. The best students were chosen for the editorial board, and they were placed in charge of reviewing manuscripts and making decisions on publication. To alleviate the anxiety of the faculty, Barak volunteered to serve as Mishpatim's first faculty advisor. As a member of that first editorial board, I recall Barak's pivotal role in guiding the students. Some of the board's meetings were held in his small apartment in Jerusalem, sometimes with his young children playing in the same living room where the meetings were held. He provided invaluable advice, and certainly exerted weighty influence. In an interview, Barak remembered that he wrote the bylaws of Mishpatim by himself, hoping to secure editorial independence for the tender board. ${ }^{32}$

as a venue to publish their scholarship." Reuven Yaron, Foreword, 1 MishPATIM 3 (1958) (Hebrew).

31 Weisman did concede that the idea of a student-run law review has its advantages However, his experience has been that each submission to the law review leads to the scholar writing a second "article" in response to the editors' criticisms, elaborating the reasons why their comments and suggestions reflect lack of sufficient understanding of the field. Interview with Joshua Weisman in Jerusalem (Apr. 10, 2008). Criticism of student-editors sitting as judges over scholarship which they do not have the skills to evaluate is widespread in the U.S. as well. In his Foreword to the first volume of Mishpatim, Dean Yaron responded to this reservation: "The frequent change of editors will prevent sinking into the conventional and will promise a fresh approach that does not hesitate to introduce necessary and useful reforms." Yaron, supra note 30, at 3.

32 Interview with Aharon Barak in Herzlia (Mar. 13, 2008). 
Barak viewed Mishpatim as an educational tool, not merely as a venue for faculty publications. The expectation and message was that the studenteditors would develop the capacity to distinguish good from bad scholarship, and that their writing skills would improve with the practice of editing. Moreover, there was a clear anticipation that students would make an effort to publish. Writing a note for the law review, Barak never tired repeating, was the best way to launch a scholarly career. ${ }^{33}$

To ensure autonomy, the law review was registered as an independent company with shares going to the dean, to two senior student-editors, and to the Center for Legislative Studies. ${ }^{34}$ Indeed, within a very short time the student-editors did develop considerable independence. The number of rejections of manuscripts was reasonably high, and the young editors seemed to have no qualms about rejecting even work submitted by senior law professors at their school. ${ }^{35}$ In one case, a lecture submitted by retired Chief Justice Simon Agranat (previously a professor at the school) was rejected as "unfit for publication in a journal oriented towards a "professional-legal audience" (the quotation marks appeared in the original). A handwritten note from the faculty advisor to the dean said: "I am very sorry about this development. I tried to prevent it but my arguments fell on deaf ears. ${ }^{136}$ Despite the apparent discomfort with the editors' decision, there is no indication in the files that the faculty sought to sway the students. The freedom of editorial discretion was honored, and evidently this by itself had an impact on the students' confidence. A report to Dean Weisman in 1982 recommended keeping the law review "as a separate and independent entity in order to preserve its autonomy." ${ }^{37}$ Despite his reservations, Weisman endorsed the report. This aspect of transplantation was surely successful.

Tel Aviv followed suit two years later. Amos Shapira, a member of the faculty's nucleus of American graduates, and then a young man intensely interested in legal education, first encountered the institution of the law

33 Indeed, the very first issue of Mishpatim contained eight student notes.

34 From a report to the University Comptroller: "The journal Mishpatim is published by a registered company ... the university established a special fund to support the expenses involved in publication." Report to University Comptroller (Apr. 1, 1982), Hebrew University Faculty of Law Archive, box 35/1, MP/3877.

35 A 1978 report to the dean states that of 26 submissions, 16 were accepted, 7 were rejected, and 3 were pending. Hebrew University Faculty of Law Archive, box 35/1.

36 Letter from Editors Tal Band and Shirley Renner to Chief Justice Agranat (Oct. 28, 1983); Undated handwritten note on the letter from Faculty Advisor Uriel Procaccia to Dean Weisman, Hebrew University Faculty of Law Archive, box 35/1.

37 Report to Dean Weisman (May 17, 1982), Hebrew University Faculty of Law Archive, box 35/1. 
review at Columbia Law School in 1962. Shapira was very impressed by the law review as an educational tool. The idea that students would be encouraged to partake in the scholarly process, write, edit, and think critically about manuscripts, was so novel and attractive that he decided to write a seminar paper about it. In an interview, he remembered approaching Kent Greenawalt, then the editor-in-chief of the law review, to learn more about the institution.

Tel Aviv's decision to establish its own law review was more circumspect than Jerusalem's. Its faculty did not trust the ability of its students to do the job independently, and preferred a more structured supervision. ${ }^{38}$ The Tel Aviv law review, Iyuney Mishpat, vested the editorial authority in a joint professor/student team. Interestingly, the professor who launched the Tel Aviv law review was not Americanized. Professor and district court judge Ze'ev Zeltner, whose legal background was decisively German, was chosen editor-in-chief, and with him as co-editor served Nili Cohen, then a fourth-year student, and now a senior professor at Tel Aviv. ${ }^{39}$ Both law reviews had trouble soliciting materials, and had to work hard to fill their pages with adequate publications. ${ }^{40}$

38 It may indeed be the case, as some of my interviewees indicated, that the level of the average Tel Aviv law student in the early 1970s (but not today) was lower than that of the average student in Jerusalem.

39 Cohen pursued her Ph.D. at Tel Aviv University, and only then spent a postdoctoral year at the University of Pennsylvania Law School. Interview with Nili Cohen in Tel Aviv (Mar. 3, 2008). The Tel Aviv Faculty went through a series of experiments concerning the composition of the editorial board. It started with a joint faculty/student team, then changed into a system where the teacher was the editor and the students were "vice editors." Today, a member of the faculty is the editor-in-chief, and an editorial board of students work under his or her authority. Nili Cohen, Iyuney Mishpat Is Thirty Years Old, 30 IYUNEY MishPAT 5 (2008) (Hebrew).

40 Interview with Nili Cohen, supra note 39; Cohen, supra note 39. As a result, many of the editors published their seminar papers as student notes. Barak remembered that when he solicited funds for the Law Review (which as an independent company needed its own financial resources) at the Ministry of Justice, he was made to promise that indeed he would see to it that four issues would be published every year. Interview with Aharon Barak, supra note 32. Cohen recalled the need to pursue potential scholars and people's hesitation to publish with the young Iyuney Mishpat when they had an opportunity to publish in Mishpatim or Ha-Praklit. Interview with Nili Cohen, supra note 39. 


\section{B. Curricular Reform: From Mandatory to Elective Menus}

The second major innovation expanding the influence of the American model was curricular reform. Again, some background information is useful. Until 1948, there were two law schools in Palestine: the Palestine Law Classes in Jerusalem, and the Higher School for Law and Economics in Tel Aviv. Following the establishment of the State of Israel, the Palestine Law Classes were closed, and the Hebrew University decided to establish a Faculty of Law. ${ }^{41}$ The young Faculty of Law was keen on emphasizing its discontinuity with the Law Classes, and on emphasizing its credentials as an academic enterprise, as distinct from a "mere professional school." It also berated the Tel Aviv School of Law and Economics, and eventually led to its closure on the ground that it was not of a sufficiently high academic level. ${ }^{42}$

To this day, and since its inception, Israeli legal education has conferred an undergraduate degree (the diploma graduates receive is the LL.B.) - a significant difference from the U.S. Most students enroll following military service, equipped with some real-life experience, but only highschool diplomas. ${ }^{43}$ The curriculum, therefore, had to resolve a problem not present in the American context: the lack of college education among the majority of the student population. The European curriculum provided an answer to this dilemma. It was based on a linear pedagogic conception, where students first received general knowledge through introductory courses, and only later were exposed to the "bread and butter" subject matters. ${ }^{44}$ Hence, in

41 The Hebrew University had already offered a program in legal studies concentrating on Jewish Law and International Law. See Likhovski, supra note 24.

42 See id.; Uri Cohen, Ha-Har Ve-Ha-Giva [The Mountain AND the Hill] (2007) (Hebrew); and Nathan Feinberg, ReminiscenCES 144 (1985) (Hebrew). Feinberg was the first dean of the faculty of law at the Hebrew University.

43 Compared to American law students, Israeli students are more mature, due to their military experience, but are less roundly educated, due to the fact that they have not attended college. From this perspective Israel is much closer to Europe and the UK than to the U.S.

44 Yoram Shachar reports that when the faculty of law at the Hebrew University was established, the small group of founders adopted the Swiss law school curriculum as presented to them by Nathan Feinberg. Yoram Shachar, Mishkan Ke-Mishpato, 19 MECHKEREY MishPAT 397, 407 (2003) (Hebrew). But note that European ideas about legal education were themselves diverse, and that there was an attempt to develop an alternative and interdisciplinary continental model in Palestine and subsequently in Israel. The Tel Aviv School of Law and Economics was founded by professors who sought an alternative to the traditional model. See Likhovski, supra note 24 . This institution did not survive the competitive spirit of the Hebrew University, which sought a monopoly over the field of higher education in Israel of the early 1950s. 
addition to the fact that the original faculty members were familiar with the European model and unfamiliar with its American counterpart, it appeared reasonable to expect that the European model would better fit the needs at hand. In the first year, students took courses such as "Introduction to the Theory of Law" and "Introduction to Roman Law," in addition to introductions to psychology, political theory, and economics. The mandatory courses, taken from the second to the fourth years of studies, were contracts, torts (until the 1970s taught as one course called "obligations"), property and civil procedure, but also labor law, tax law, conflicts of laws, and public international law. ${ }^{45}$ The senior professors were kings of their fields, and any young professor joining the faculty and teaching in their area served under them and depended on their goodwill for career development, a fact that in all probability encouraged conformism and put a damper on thoughts about reform. It should also be emphasized that the model of the Israeli law school bore British influence as well. The British presence in Palestine had a decisive influence on Israeli law. In addition to substantive influence on the legal system, the Palestine law classes offered prospective lawyers the same legal education prevailing in other British colonies. In addition, many went to seek their legal education in London (examples include Itzhak Olshan and Moshe Landau, who both later served as Chief Justices of the Israeli supreme Court) and returned convinced that they had acquired the best legal education there was. Legal historian David Sugarman has analyzed the "black letter" law tradition in English legal education, complete with the emphasis on textbooks, doctrine, the higher status of judges compared to professors, the superiority of the status quo compared to reform, frontal lecturing, and drilling as a mechanism to instill the case law in the minds of students. All of these elements may be found in one form or another in Israeli legal education. ${ }^{46}$

In addition, the Hebrew University's leadership was uncomfortable with fields of study that had a "professional" orientation. This factor may have influenced the determination of the founders to present law as a "pure discipline" rather than as a system connected to society and politics. For the University's chilly attitude towards professional training, see Gross, Economics Before Patinkin, supra note 18, at 10.

45 Contracts and torts were taught sequentially, in a one-year-long course, as "obligations."

46 For David Sugarman's work, see David Sugarman, "A Hatred of Disorder": Legal Science, Liberalism and Imperialism, in DANGEROUS SuPPLEMENTS: RESISTANCE AND RENEWAL IN JURISPRUDENCE 34 (Peter Fitzpatrick ed., 1991) and references therein. Concerning the promotion of law professors one should recall that they are subject to the same rules that apply across the university. Scholarships provided for bright Israeli students to study in the U.K., particularly in Oxford and Cambrdige, enhanced the attachment to the British tradition. Students who graduated from these universities retained a sense of the superiority of English legal education over the 
Both universities began a movement for curricular reform in the late 1960s with the abolition of the monopoly of the senior professors over their respective fields. ${ }^{47}$ Thus, curricular reform reflected not only American influence, but also a generational shift. The retirement, or the impending retirement, of the old guard opened a window to change and innovation. In both law faculties, reform was inspired by the American model. ${ }^{48}$

As noted, Barak and Zamir returned from Harvard Law School firmly convinced of the need to engineer reform. But the skepticism of their senior colleagues was considerable, and reform had to wait until the retirement of the old guard and the arrival of a new group of young teachers. It should be noted that at the Hebrew University the impetus for change also emerged from below. In 1973, one finds a letter to the editor penned by Baruch Avrahami, one of Mishpatim's editors, titled "Give Us a Faculty for Lawyers." ${ }^{49}$ The young editor, evidently one of the better students in the faculty (only high achievers were appointed to the editorial board), complained bitterly of the archaic curriculum which failed to expose students to many of the fields of law in daily practice. The subsequent issue of Mishpatim included responses from two members of the faculty, one totally rejecting the student's complaints, the other mildly agreeing that some reform was indeed needed. ${ }^{50} \mathrm{~A}$ third response, by a young lecturer

education provided in the U.S. and also tended to deny the absence of "law and ..." scholarship in the U.K. Interview with Yoram Shachar in Jerusalem (Mar. 9, 2008). As for the system of promotion mentioned in this paragraph: to this day, promotion in Israeli universities is known as a "via dolorosa." One starts with the rank of a "lecturer" (sometimes with a lesser rank), and then has to jump through the hoops of senior lecturer, associate professor, and full professor. Each stage requires full academic evaluation.

47 Interview with Joshua Weisman, supra note 31 . This monopoly was known as the "latifundia system" - the system known for concentrating large parcels of land in the hands of the wealthy few.

48 See Asher D. Grunis, Legal Education in Israel: The Experience of Tel-Aviv Law School, 27 J. LEGAL EDUC. 203 (1975) (providing a historical overview and a comparison of the curricula at Jerusalem and Tel Aviv).

49 Baruch Avrahami, Give Us a Faculty for Lawyers, 4 MishPATIM 225 (1973) (Hebrew).

50 Itzhak Englard, Give Us Students Who Will Study Law, 4 MishPATIM 743 (1973) (Hebrew). Englard defended the status quo, and blamed the philistinism of the students for any malaise. His position was that the students, not the faculty, should change. The other response was by Itzhak Zamir, The Other Side of the Faculty, 4 MishPATIM 745 (1973) (Hebrew). Zamir sounded more conciliatory, supported change, and even expressed a willingness to turn his course, labor law, into an elective. Id. at 748. Taken together, the attitudes of Englard, Zamir, and Shetreet 
at Tel Aviv University, enthusiastically endorsed the call for curricular reform..$^{51}$

Being rather young, it is reasonable to expect that the faculty of Tel Aviv University was less encumbered by institutional tradition and more able to promote reform. Amnon Rubinstein, then dean at the newly independent Faculty of Law at Tel Aviv, ${ }^{52}$ was attracted to the American way of teaching law, even though (or perhaps because) he himself was a graduate of the London School of Economics. In an interview, he recalled sending for and studying the curricula of the major American law schools. ${ }^{53}$ His agenda for reform was revolutionary for his time: fewer mandatory courses, and more electives. Rubinstein was a dynamic dean, eager to lead his young faculty into the modern age, which he identified with the United States. He also enjoyed the advantage that most (not all) of the older guard at the Tel Aviv Faculty of Law were fulltime practitioners who did not wish to be too involved in the life of the faculty, and therefore were less determined to fight the "Young Turks." ${ }^{44}$ Assisting him were Professor Daniel Friedmann and members of the younger generation. ${ }^{55}$

(see infra p. 676) easily explain why enthusiasm for reform in Jerusalem was rather lukewarm.

51 Amos Shapira, Give Us Appropriate Legal Education, 4 MishPATIM 739 (1973) (Hebrew). Another version of this response was Amos Shapira, Legal Education and the Public Interest, 15 HA-UnIVERSITA 26 (1969) (Hebrew).

52 The first dean of the independent Faculty of Law at Tel Aviv was Gualtiero Procaccia, who studied law in Italy, and served as professor of Roman law and corporate law.

53 Interview with Amnon Rubinstein in Herzlia (Apr. 13, 2008). Rubinstein studied both law and economics at the Hebrew University, and expressed admiration for the rigorous and interactive study at the faculty of economics compared with the lethargic instruction at the faculty of law. The faculty of economics, the reader should recall, was formed and led by a graduate of the University of Chicago. See supra note 18. In the archives of the Tel Aviv Faculty of Law, attached to the report on curricular reform, there is a collection of documents from the law schools at the Universities of California (Berkeley), Stanford, Pennsylvania, Virginia, Chicago, George Washington, Illinois, and Wisconsin. Id. Curiously, the curricula of the Harvard and Yale Law Schools do not appear in this collection. This may be an archival omission, or based on the fact that the reformers were already familiar with these curricula. At the Hebrew University in Jerusalem, the reform was less extensive. For a detailed discussion, see Grunis, supra note 48.

54 Rubinstein was also a public intellectual, involved in the affairs of state, and soon established a political party and left the university. His public profile appealed to students who were attracted to the connection between law and politics. It could be that Rubinstein's retirement left the Tel Aviv law school under the influence of the continental European tradition, and retarded the process of Americanization, but not before he had instituted significant reform, as documented by Grunis, supra note 48 .

55 Shapira followed Friedmann to the deanship of Tel Aviv University, increasing the ties with the U.S. of which he was very supportive. David Libai, another member 
From the 1970s to the 1990s, both faculties introduced curricular reform in small incremental steps. Several introductory courses were eliminated or became electives, substantive courses such as criminal law and contract law moved into the first year, and electives and seminars were added. In addition, the requirement of moot court coupled with instruction on legal argumentation was added. ${ }^{56}$ It appears that Tel Aviv was the pioneer in introducing curricular reform, and that Jerusalem lagged a bit behind ${ }^{57}$ Uriel Procaccia, who was appointed dean in Jerusalem in 1990, remembered the resistance of the senior members of the faculty, particularly to the idea that their courses would become elective instead of remaining part of the core curriculum. His offer to turn his own course, corporations, into an elective, served as a serious incentive to others to give in and accept the new plan. ${ }^{58}$

of the young generation, turned to criminal defense practice and to politics, and between 1992-1996 served as Israel's Minister of Justice under the (second) Rabin government and the short-lived Peres government.

56 Frishman, supra note 26, at 18-20, 31.

57 See Grunis, supra note 48, at 218. Cf. Celia Fassberg, Daphne Barak-Erez, Comment on Pnina Lahav (June 9, 2008) (unpublished comment, presented at the Cegla Center conference on Histories of Legal Transplantations, on file with author) (discussing the 1990s reforms and stating that Jerusalem led the curricular reform).

58 E-mail from Professor Procaccia (June 18, 2008) (on file with author). In addition to curricular reform, Procaccia also introduced a grading reform, and integrated the idea of commitment to the public interest as a part of legal education. Procaccia also observed a connection between these reforms and the slow shift from formalist scholarship to a recognition that "black-letter law erudition is not at the heart of our project." Id. Procaccia also presented himself as "exhibit A" of the changes that Israeli legal scholars had undergone since the 1970s. As a young lecturer in the early 1970s, he recalled, he was not aware that there were other ways of thinking about the law (despite his graduate work at the law school of the University of Pennsylvania). When he embarked on a joint research project with David Kretzmer (then a young lecturer, the only person on the faculty familiar with theories of law and economics), he heard Kretzmer announce that a particular legal rule was not "efficient." Procaccia remembered being startled by this characterization, as he did not know how efficiency was relevant to the legal analysis at hand. Id. Thereafter, Procaccia studied economics at the Hebrew University, published scholarship within this discipline, and became the founding father of the field of law and economics in Israel. (Kretzmer, an expert on a number of legal fields, went on to establish himself as a renowned authority on international law and human rights.) His influence may explain the fact that today the Faculty of Law at the Hebrew University is particularly strong in law and economics, in addition to analytical jurisprudence. The component of analytical jurisprudence, clearly an English (Oxfordian) legacy, represented by such luminaries as Ruth Gavison, Hanina Ben-Menachem, and Alon Harel (it should be added that preeminent philosopher Joseph Raz is a graduate of the Hebrew University Faculty of Law and taught there briefly as a young lecturer 
One does not see a blind imitation of the American model in these reforms ${ }^{59}$ For example, courses such as property law and civil procedure never became a part of the first-year curriculum. ${ }^{60}$ In addition, both faculties retained a component of general education in the first-year curriculum. ${ }^{61}$ However, the idea of exposing students to substantive law in the first year and the emphasis on electives were certainly American, and they were enthusiastically embraced by the young faculties of both law schools.

\section{Teaching Method: From Frontal Lectures to Class Discussion ${ }^{62}$}

The third innovation, and the one that proved to be most contentious, was the introduction of more lively teaching methods. Throughout the 1950s and 1960s, the conventional method of teaching at both faculties of law was frontal lecturing, also known as lectures "ex cathedra." ${ }^{63}$ The professor would come to class, generally sit down and dictate a lecture, which

in the late 1960s), may have contributed to the antipathy to "law and . . ." courses at the Hebrew University during the 1970s and 1980s.

59 One interesting difference is the focus on comparative law. Comparative law has always been an important aspect of Israeli legal education and scholarship, long before it attracted attention in the United States. For a thoughtful analysis, see Ron Harris, Rethinking the Rationale for Teaching Comparative Law in Israel, 25 IYUNEY MISHPAT 443 (2001) (Hebrew).

60 The field of civil procedure is an interesting example of the differences that separate the Israeli from the U.S. model. Federalism makes the teaching of civil procedure in the first year an important part of the introduction of students to the distinction between federal and state law. In Israel, this distinction is irrelevant, and civil procedure therefore occupies a less fundamental role in the curriculum. This difference also appears as one of the factors Weisman lists for rejecting the American teaching method. Weisman, On the Teaching of Law, supra note 7.

61 At Tel Aviv University, students have to choose two courses from a cluster of courses called "meta-legal" courses. One of these courses should be taken in the first year. The courses include Law and History, Law and Feminism, Legal Systems (emphasizing comparative law), Theories of State and Morality, Law, Society and Culture, and Law and Economics. At the Hebrew University, three introductory courses are mandatory in the first year: Jurisprudence, Legal Systems, and Introduction to Jewish Law.

62 According to the Israeli Index of Legal Periodicals, thirty-eight scholarly articles have been published in Hebrew on the topic of legal education in Israel. The discussion below mentions only a few of these. I apologize to the authors whose work is not cited herein. This is by no means a reflection on the quality of their work.

63 Latin for "from the chair," denoting the professor's chair, but also the authority with which the text is delivered. The term is used in Catholic theology to denote 
the students would copy diligently into their notebooks. Only rarely were students invited to question the knowledge thus transmitted. If someone did dare interrupt the lecture by posing a question, the answer was usually short and authoritative. There were no office hours, and professors had minimal interaction with students. The professors considered the body of knowledge to be fixed and predetermined, and therefore barely changed their lectures from year to year. ${ }^{64}$ In the beginning of the course the professor would recommend reading materials, but there was little reading requirement for any specific class. Sections were attached to the required courses, attendance was sometimes mandatory, and cases were assigned for reading. There were no casebooks or mimeographed materials, and students were expected to read the cases in the library. The sections mostly consisted of dull and tedious rehearsals of the facts contained in those cases..$^{65} \mathrm{~A}$ culture therefore developed whereby students did not attend classes, and instead relied on mimeographed materials, which were either sold or passed on from one generation to the next. Sometimes a particularly bright or entrepreneurial student would gather the professor's notes and publish them with the students' publishing house. The young student Aharon Barak did this himself when, in 1956, he prepared for publication his notes from Gad Tedeschi's course, "Introduction to the Theory of Law."66

Evidently, it takes one very versed in the old system to understand its limitations. Barak himself was a gifted teacher, and his experience at Harvard Law School propelled him towards a different mode of instruction. On his return, he conducted classes where questions were asked and dialogues with

the infallibility of the Pope. By implication, its use in the university environment designated the infallibility of the professor.

64 Of course, the lectures did reflect new judicial opinions, but often the professors would delegate the study of new cases to the sections.

65 If the professor felt he could not complete the lectures due to time constraints, he would sometimes ask the teaching assistant ("metargel," known in U.S. colleges as section leader) to shift to lecture mode. In an interview with Amos Shapira, I learned about the title "me-sha-nen," which he thought was "tutor." Interview with Amos Shapira, supra note 23. Literally, it means "repeater" or "rehearser." The idea conveyed is that of someone who helps the students memorize facts. Barak did not recall this term, but conceded that this was the nature of the instruction. Interview with Aharon Barak, supra note 32.

66 GAd Tedeschi, InTROdUCtion to THE THEORY OF LAW (Aharon Barak ed., 1956) (Hebrew). Other examples are SHALEV GinOSSAR, EvidENCE (Eliahu Harnon ed., 1956) (Hebrew); Shalev Ginossar, Civil Procedure (Aharon Barak ed., 1957) (Hebrew). Generally, the professors did not oppose publication, but insisted that it include the caveat that the professor did not review these notes. 
students were welcome and encouraged. This was not the typical Socratic method as immortalized by the figure of Professor Kingsfield in the film The Paper Chase. Barak was warm and gentle, and his demeanor always reflected love of knowledge and immense curiosity. Questions were probed in the true spirit of deepening understanding ${ }^{67}$ In the fall of 1967, for the first time Barak taught a course in tort law (until then the subject was part of a course known as obligations, where contracts and torts were taught backto-back, as is the custom in continental Europe). He chose David Kretzmer, one of his most brilliant LL.M. students, and later an eminent professor at the Hebrew University, to lead the sections. Kretzmer's method of instruction was particularly challenging and, at least to the students, appeared to fit Barak's style hand in glove. Kretzmer distributed sheets with legal problems, required prior reading by way of preparation for the analysis of these problems, and in class proceeded to dissect the problems instead of rehearsing the reading materials.

I should pause and disclose that I have always been under the impression that the problem method of legal instruction was another innovation brought over from Harvard Law School by Barak. But I was wrong. It turns out that the young Kretzmer was not aware of the American pedigree of this method. He borrowed the problem method from the property law course taught two years earlier by Joshua Weisman. ${ }^{68}$ Weisman, a graduate of the second class of the Faculty of Law at the Hebrew University, obtained his Ph.D. also from the Hebrew University. ${ }^{69}$ In an interview, Weisman recalled how he came by himself to the problem method as a preferred mode of teaching. He was unhappy with the frontal lecture and was looking for ways to enliven the class and encourage the students to think analytically. Merely teaching cases (the Langdellian case method, discussed below) did not satisfy him, as he did not wish to discuss what courts had already resolved, but rather to apply legal knowledge to new problems. ${ }^{70}$ Weisman was surprised to realize, upon arrival

67 These, at least, are my own recollections as a law student in 1968.

68 Interview with David Kretzmer in Jerusalem (Mar. 27, 2008).

69 Weisman did spend a year at the London School of Economics during his years as a doctoral student, but did not recall encountering a different teaching method there.

70 Weisman recalled that students did complain bitterly about this teaching method, which forced them to read and prepare for class in a manner unprecedented. $\mathrm{He}$ acquired the reputation of a "hard teacher." In the days before student teaching evaluations, when popularity was not a factor, this was not considered a serious impediment. I treat this phenomenon as an aspect of transplantation. The topic of transplantation has grown into a serious industry since Alan Watson's seminal work, ALAN WATSON, LEGAL TRANSPLANTS: AN APPROACH TO COMPARATIVE LAW (1974). 
at Harvard Law School on the heels of Barak and Zamir in the fall of 1967, that the problem method was ascendant there as well.

This point deserves emphasis. No one will deny that the American teaching method had significant influence on Israel. Still, not everything that looks similar, or even identical, was actually imported. It is quite possible that similar pedagogic solutions developed at the same time in different parts of the world. The fact that one country is an empire and the other a remote province should not lead one to jump to the conclusion that the province imported from the center. The independent development of the sophisticated and demanding problem method is an excellent example of the need to address transplantation carefully and skeptically. Something that looks like a transplant may, in fact, be homegrown.

At Tel Aviv, the younger faculty was also eager to introduce new teaching techniques. Amnon Rubinstein recalled in an interview that, as Dean, he was keen on discussion and made efforts to encourage his colleagues to do likewise. ${ }^{71}$ The spirit of reform was in the air, and itself became the subject of scholarship. In 1972, Amos Shapira published an article titled Changing Patterns in Legal Education in Israel. ${ }^{72}$ Shapira was enthusiastically reporting to the world, in English, that Tel Aviv was engaged in curricular reforms, and called for these reforms to be "coupled with effective teaching."73 Shapira's description of the ideal method of teaching reflects both the dream and the reality of legal education at both Jerusalem and Tel Aviv at the time: effective teaching "would mean, first and foremost, relinquishing the formal lecture ex cathedra as the principal method of instruction. Lecturing should be replaced by dialogue, by group discussion, by a process of give and take shared by teachers and students.... Mechanical note-taking and memorizing should give way to independent thinking and a critical approach."174

The scholar Shapira was mindful of the distinction between the "is" and the "ought." After two full pages describing the ideal teaching method, he returned to the reality and stated that "[t]he Tel Aviv University Law School is making genuine efforts to render law teaching more effective," and that "[e]ver more faculty members are abandoning pure lecturing in favor of class discussions." He was careful not to be more specific than

In this Article I am using this term of art in a minimalist sense and do not address the theoretical complexity it entails.

71 Interview with Amnon Rubinstein, supra note 53.

72 Amos Shapira, Changing Patterns in Legal Education in Israel, 24 ADMIN. L. REV. 233 (1972); see also Grunis, supra note 48.

73 Grunis, supra note 48, at 241.

74 Id. 
"ever more. ${ }^{175}$ It is safe to say that at the time of Shapira's writing only very few professors were moving to class discussions, and that the majority, at both Tel Aviv and Jerusalem, were not terribly excited about these new ideas. Yet Shapira clearly was observing something real.

The new spirit could be poured into several American vessels, not all identical. There was the Socratic method associated with Langdell, designed to "discover" great principles of law and doctrine through a close session of questions and answers in the classroom. This method, as all know, was linked to the case method, as the assigned materials were leading judicial opinions. There was the problem method, distinguished from the case method because it consciously avoided a solution or result. The legal solution had to be developed by the students on the basis of the assigned materials. This method required intense work on the part of both teachers and students. Finally, there was the more loosely defined "discussion method," meant to enliven the class through debate and deliberation. There was a basic difference between the first two methods and the third. Whereas the first two emphasized arguments internal to the law, the third invited arguments from legal policy, mixing internal with external ("law and ...") arguments. Americans are likely to recognize the grand tension and debate between the Yale and Harvard law schools in matters of legal education, so vibrantly discussed by historian Laura Kalman. ${ }^{76}$ Indeed, Shapira himself was a graduate of Columbia and Yale whereas Barak and Zamir were heavily influenced by the Harvard approach.

The frontal lecture stood shamed and dwarfed before these "new age" methods, and yet it too had pedagogic justifications. As originally conceived,

75 One more signal of the changing approach to legal education must be mentioned, and this is the examination. The conventional method of testing, the closed book examination, was challenged by Barak upon his return from Harvard Law School. He recalled telling the students, "you may bring anything, all your books, your notes, you may come with full suitcases of materials if you wish. In the examination you need to apply your knowledge, not regurgitate." This was a radical innovation, which had a thrilling impact on the students, who suddenly experienced agency as an integral part of the educational experience. Interview with Aharon Barak, supra note 32. Similar innovations took place at Tel Aviv. See Grunis, supra note 48.

76 Laura Kalman, Legal Realism at Yale, 1927-1960 (1986); LaURA Kalman, Yale LaW School and the SiXTIES (2005). See also Robert W. Gordon, Professors and Policy Makers, in History OF THE Yale LAW SCHOOL 75 (Anthony T. Kronman ed., 2005); It is also interesting to note that since the 1980s, Barak has developed a deep and meaningful relationship with the Yale Law School, which may have influenced him to balance his devotion to doctrine with an analysis of the purposes (policy) of the law. 
the lecture method was designed to give the students a coherent, systematic review of any particular field of law. If one accepts the premise that students do not read (or worse, barely attend class), then the method of discussion may not stimulate intellectual rigor, but rather reinforce less understanding, and more shallow thinking.

These points appeared clearly in the debate on the pages of Mishpatim in the early 1970s, already mentioned above. In his short polemical essay, the student Baruch Avrahami attacked the frontal lecture and called for an introduction of the Socratic method. ${ }^{77}$ Shimon Shetreet, at the time a young member of the faculty of the Hebrew University, a graduate of the University of Chicago, and today a senior professor, showed that the disagreement crossed generational lines, and that not all of the young favored reform. New teaching methods cannot work in Israel, Shetreet wrote in his apologetic response to the editor, because the students would not cooperate: "the Israeli student, unfortunately, does not want to and cannot (because of more difficult objective conditions) withstand the academic pressure like his American peer. Therefore, it is not possible to adopt in Israel the Socratic method wholesale." "The Socratic method," he wrote, "is conducted with great aggression by the professor and intense emotional pressure is placed on the students, which contributes nothing to the cause." Shetreet was also critical of the problem method: "it is an excellent system for the good student but not for a less able or weak student and it leads the student to see the law as a collection of cases, not as a harmonious system."178

The debate continued. To avoid discord, the faculties adopted a variation of Chairman Mao's slogan: "let a thousand flowers bloom."79 The various teaching methods coexisted, as they presumably have done ever since. It is quite reasonable to assume, on the basis of recollections by many interviewed faculty members, that the frontal lecture remained the predominant teaching method, but that the pockets of innovation were growing. New appointments

77 Avrahami, supra note 49. After criticizing the lecture method, Avrahami called for "a class where the student takes an active part." As "active part," he listed "the case method, class discussion, and moot courts." Id. at 226.

78 Shimon Shetreet, Letter to the Editor (unpublished, on file with author). Itzhak Englard and Itzhak Zamir also responded. Englard's response was a thorough apology for the existing system, whereas Zamir, while disagreeing with Avrahami, pointed out that the faculty was beginning to introduce the discussion method in the classroom. Englard, supra note 50; Zamir, supra note 50.

79 The original Mao slogan was "let a hundred flowers bloom, let a hundred schools of thought contend." I heard the phrase from both Barak and Amos Shapira in their interviews. 
to the faculties, persons who returned with an S.J.D., or faculty members who visited the U.S. for extended periods of time, experimented with more open teaching methods, and struggled with adjusting them to the prevailing practice.

\section{Resistance, Intimate Links Between Teaching and Legal Thought Exposed}

In 1982, this "live and let live" approach was publicly challenged when Joshua Weisman, then dean of the Faculty of Law in Jerusalem, delivered his attack, already mentioned above:

The exposure of law professors in Israel to the conventional pedagogic approach in law schools in the United States harbors a risk that upon returning to Israel the professor will teach his students what he has studied, not what they should learn. ${ }^{80}$

The reader may remember that it was Weisman himself who had developed the problem method, unaware that it was being developed in the United States as well. Evidently, his arrow was not targeted at the problem method. Weisman distinguished between two approaches to legal education. One was technical, doctrinal, and cabined within the four corners of the law as traditionally conceived. Its rival was a discussion based upon "broad policy considerations," a discussion which investigated the general principles underlying the technical legal problem. It is safe to say that Weisman was advocating a pedagogic method that would give center stage to arguments internal to the law. In his opening remarks, Weisman conceded that the policy method, allowing external factors to be weighed in, was more interesting and appealing to students, but he insisted that professionalism and precision were thereby lost or compromised. Weisman did his homework well. He put together a list of eight factors distinguishing Israel from the United

80 Weisman, On the Teaching of Law, supra note 7. Weisman's attack was delivered the previous year (1982) at an international conference on legal education at the Faculty of Law at Tel Aviv University. Weisman, The Relevance of the American Experience, supra note 7. At about the same time, Itzhak Englard, also of the Faculty of Law at the Hebrew University, denounced the Socratic method as a tool used by evil persons (he referred to the fictitious Professor Kingsfield in The Paper Chase). Englard also opined that teaching methods were secondary to students' ability and motivation, and mentioned the frontal lecture respectfully. Englard based his remarks on continental European sources exclusively. Itzhak Englard, Reflections About the Faculty of Law, 12 MishPATIM 217 (1982) (Hebrew). 
States and which, therefore, militated against the "policy-oriented" method of deliberation in the law school classroom.

Of these eight, I shall focus on the first, which I intuit was also the most important, and where the attack on the policy-oriented method is clearest. ${ }^{81}$ Weisman contended that in the United States the presence of the written Constitution was critical. Legal professionals were required to evaluate the validity of legislation under the Constitution, and consequently had to take into consideration the broad principles embedded in the fundamental document. In contradistinction, Israel had no constitution, parliament was supreme, and its legal professionals were concerned merely with legislative acts. Weisman illustrated the difference by an example. In the United States, a legal professional would ask "does the particular legislative act fit the general principles embedded in the Constitution?" By contrast, in Israel, professionals were only asking "what does the statute say?"82 While advocating caution, while conceding that policy considerations should occasionally enter the classroom, and while certainly agreeing that the baby should not be thrown out with the bathwater, Weisman was delivering an attack on U.S. legal education, as it was experienced in the 1980s. His eight factors only sharpened the differences between Israel and the United States, and therefore underscored the need to chill the reception of American influence on the law faculties. ${ }^{83}$

The key to understanding Weisman's objection is his strategy in framing

81 The other seven were, in the following order: (1) federalism, which leads to the operation of American law schools as national schools with minimal emphasis on the technical aspects of any one state's legal system; (2) codification, which is a central part of Israel's private law, and which requires close attention to legislation; (3) the fact that Israel requires a period of clerkship where young graduates are trained by attorneys prior to taking the bar exams (it is not clear whether this point works to support or challenge Weisman's major idea, but I shall not get into this here); (4) the fact that Israelis, unlike their peers in the U.S., come to law school without college education, and therefore are not as equipped to discuss policy issues; (5) the lack, in Israel, of published textbooks and casebooks, which facilitate access to knowledge; (6) the fact that in the U.S., lawyers are allowed to advertise their skills means that they lean toward specialization, whereas in Israel self-advertising is prohibited, and therefore the tendency to specialize is weaker; and (7) in the U.S. there is very little emphasis on comparative law, whereas in Israel the tendency to consult "how other countries have approached the problem" is prevalent. The purpose of this Article is not to critically examine Weisman's list of factors, and therefore I do not go beyond offering a description. Some of the factors on his list seem to be no longer relevant.

82 Weisman, On the Teaching of Law, supra note 7.

83 In all probability, Weisman was not against exposure to American legal education. Rather, he probably thought that it would be better to educate the next cadre of law teachers in Israel and, only then, when they were rather mature and committed to 
his question. Weisman frames the difference between the two legal systems in terms of the tasks facing each legal community. Are the tasks of both communities similar, he asks? His answer is that they are not. ${ }^{84}$ Israelis are charged with merely interpreting legislative acts, whereas Americans must consider the impact of the Constitution. This way of framing the difference allowed Weisman to divert attention from the deeper question of the meaning of law. Weisman assumed that all agreed that law was a set of given rules awaiting interpretation. If, however, law is a part of a broader and complex web of social phenomena, then all norms, whether found in the tax code or in the Constitution, require an equally intensive investigation into their deeper meaning, as well as into their policy ramifications. ${ }^{85}$

So understood, Weisman's attack was not really on the "American teaching style," but rather on contemporary American legal thought. It was a plea to retain law as a closed system of rules and restrict the discussion to the internal legal arguments, rather than to shift the understanding to law as a social system which reflects and interacts with other social systems. It is here that the connection between teaching method and scholarship is most evident. Legal scholarship will differ, depending upon whether one believes law to be a closed or open-ended system. Hidden inside the message that law should be taught as a closed system was also a message that true scholarship was scholarship of "pure law." I shall return briefly to this connection below, even though I should again remind the reader that my subject matter is legal education, not legal research and scholarship. ${ }^{86}$

In 1982, Weisman was making a heroic effort to clip the wings of a bird that was already airborne. Already a decade before Weisman delivered his attack, Amos Shapira eloquently announced the need to shift to a different understanding of law:

A functional legal education must, first and foremost, abandon the illusion that law is a "pure" discipline, hovering in a conceptual universe all to itself, hermetically sealed off from the other social

the "Israeli way of thinking," to send them for a postdoctoral year in the U.S. like he himself had done.

84 In interview, Weisman stated that this point may be obsolete, because Israel today does have a form of a constitution. Interview with Joshua Weisman, supra note 31.

85 Weisman did understand this issue, and later in his presentation conceded that "considerations of general policy are not absent from the Israeli judicial process." But he did insist that in Israel there is, and should be, less emphasis on policy considerations.

86 Again, this is proof that the scholarship produced at the law school and legal education are intimately connected. 
sciences. . . Logical deductions from abstract legal doctrines cannot provide the judge with ... ready-made answer[s]. In short: the complex problems confronting modern society involve, almost invariably, the different aspects of the social process. ${ }^{87}$

A decade before Weisman suggested that there was a distinction between public law and private law, and that private law should be taught as a closed system of rules, Shapira already protested that such an approach was ill advised:

It is meaningless ... to examine currently proposed auto compensation plans separately from economic and sociological questions, such as: how the substitution of fault as criterion of liability by a principle of strict liability (linked to an insurance scheme of one sort or another) is likely to affect the car industry? The development of new and better safety devices? The number and severity of car accidents? The propensity of drivers and pedestrians to behave more - or less prudently? The profits of the insurance industry? The case-load of trial courts? The business of the legal profession? The claim consciousness of accident victims? ${ }^{98}$

One is tempted to think of Dean Weisman as one of the last Mohicans trying to stop the "hostile" takeover, or that Shapira's eloquent call for interdisciplinary study (he devoted an entire section in his article to its virtues) and a broad understanding of law won the day. But this was not the case ${ }^{89}$ Indeed, Shapira was not alone in his criticism. Dean Amnon Rubinstein at Tel Aviv was an ardent supporter of the "law and ..." movement, as were many others. ${ }^{90}$ And yet Weisman represented a strong camp, resentful of the

87 Shapira, supra note 72, at 237. Shapira, of course, was not alone. His dean at the time, Amnon Rubinstein, was an avowed supporter of the "law and ..." movement, and a firm believer in the need for interdisciplinary study. Interview with Amnon Rubinstein, supra note 53. Note too that Shapira is advocating the adoption of the interdisciplinary approach developed at Yale Law School, whereas Weisman may be said to be echoing a permutation of the Langdellian approach prevalent at Harvard in the 1960s. See supra note 76.

88 Shapira, supra note 72 , at 237.

89 In fact, their disagreement reflects two stages of globalization. See Duncan Kennedy, Two Globalizations of Law and Legal Thought, 1850-1968, 36 SUfFOLK U. L. REV. 631 (2003). Kennedy discusses the struggle between classical legal theory, prevalent in Europe during the 19th century, and "The Social," which perceives law as social engineering. Id. at 2.

90 Among them Uriel Reichman, Yoram Shachar, and Leon Shellef. 
"American way" and determined to flag the fundamental differences between the Israeli legal system and that of the United States.

The struggle continued. One indication of the tenacity with which the "anti-American" camp held to its approach, and its success on the ground, is the fact that successive generations of brilliant Israeli law graduates, who went on to study in the elite law schools in the United States, repeatedly echoed the same observations made by Shapira. Persons who graduated through the 1990s (I was asked not to name names) reported that they arrived in the United States confident that they "understood what law is," only to realize that they were provincial and ignorant. Half jokingly, one graduate of the 1990s, who has made a brilliant career, reported that "in JFK [airport, arriving in the U.S.] we came down from the trees." Of course, there were those who obtained training in other disciplines prior to arriving in the U.S., and they had an easier time and did not feel so ignorant, but many agreed that their Israeli training was mostly of law as a closed system. In short, the majority felt that Israeli legal education followed the Weisman, not the Shapira, model.

In fact, it is even arguable that Shapira himself did not march to the tune of his own pipe. In an interview, he conceded that when he was writing in the early 1970s, he was too much of a true believer (an Alice in Wonderland, one might say), and that he later changed his mind. It may well be that he was co-opted by the predominant culture of the time, and that the resistance led by Dean Weisman and his cohort convinced him that he could not "beat them," and "joining them" would better comport with self-preservation. Be that as it may, more holders of an American S.J.D. joined the ranks of the law faculties, and more members of the faculties served as visiting professors in the U.S. and returned convinced that change was necessary. ${ }^{91}$

In 1990, the new dean of the Faculty of Law at the Hebrew University, Uriel Procaccia, delivered a speech to the entering class, later published under

91 By that time, the Hebrew University in Jerusalem had an exchange teaching program with the Law School at U.S.C., and many members of the faculty spent a year of teaching and research at that institution. U.S.C. was an energetic and innovative law school, known for its penchant for legal thought. The Tel Aviv Faculty of Law had an exchange teaching program with Temple Law School, and its faculty members also gained access to the American approach to legal education. Some of them also took advantage of the exchange program at U.S.C. Occasionally, an Israeli law professor would be invited to an elite law school in the U.S. as a visiting professor. Two examples are Ruth Gavison, who taught at Yale Law School in the late 1970s and early 1980s, and Menachem Mautner, who taught at the University of Michigan School of Law in between 1988 and 1991. 
the title "Legal Bubbles." ${ }^{92}$ It was a bold attack, conceded to be polemical by its author, on the "pure theory of law," and a call to adopt an interdisciplinary approach to law, "or as one of the best scholars in our generation has called it, 'law and ...." 93 Procaccia specifically rejected the position taken by the old guard of the faculty that law is independent of society, insisting to the contrary that law is socially constructed and needs to be explored through the lens of the various social disciplines, from economics (his favorite) to sociology, philosophy and more. ${ }^{94} \mathrm{He}$ concluded by welcoming the entering class into the "most interesting profession in the universe, a profession that precisely because of its substantive emptiness, contains everything." Procaccia was promising the new law students that legal education could be fascinating and exciting, not dry and boring. The way one taught law was thereby mixed into the substance of what was taught and presented as a single whole.

What was the difference between Procaccia of the 1990s and Shapira of the 1970s? Only that Procaccia was now dean, and had amassed enough support and determination to implement reform. ${ }^{95}$ In Tel Aviv, the younger generation was also watching, eager to seize the day. Dean Ariel Rosen-Zvi, a scholar committed to innovation even though he had little exposure to the United States, encouraged a young law professor, Menachem Mautner, to contribute an article on legal education to his new journal (the proliferation of publications was another signal of change).${ }^{96}$ Mautner, a gifted teacher and scholar, accepted the invitation. He elaborated on Amos Shapira's themes. He rejected the formalistic approach, extolled the virtues of interdisciplinary study, and called for the adoption of a different paradigm of thinking about the law, in keeping with the "new paradigm" of legal thought. ${ }^{97}$ In a footnote, Mautner did mention that his senior colleagues, such as Amos Shapira at Tel Aviv, and a few at the Hebrew University, had advocated the same two decades

92 Uriel Procaccia, Legal Bubbles, 20 MishPATIM 9 (1990) (Hebrew).

93 Id. at 17 and 10, respectively. (Procaccia relied on the seminal article by Yale Law professor Arthur Allen Leff, Law and, 87 YALE L.J. 989 (1978).)

94 Id. at. 11. Procaccia specifically referred to two senior professors: Avigdor Levontin and S.Z. Feller, the latter known for referring to the "law and . . ." approach as "parasitology," i.e., legal scholars who drew on other disciplines were parasites, inauthentic.

95 See supra note 58.

96 Ariel Rosen-Zvi, a scholar of family law, was an extremely erudite and broadminded man whose commitment to a more meaningful system of legal education and better scholarship cannot be sufficiently recorded here. His untimely death did not permit him to fulfill his potential as a leader and reformer.

97 Menachem Mautner, The Law School: Between the University, the Bar and the Courts, 1992-1993 Y.B. ISR. L. 1 (Hebrew). 
earlier, but he did not pause to reflect on the reasons why, despite their efforts, the "formalistic" and "traditional" approaches still prevailed. ${ }^{98}$ Nor did he deny the fact that his article was inspired by the long years he had spent in the United States. ${ }^{99}$ Rather, like Shapira two decades earlier, Mautner announced that the "new paradigm" of interdisciplinary study was on the ascendant.

Indeed it was. By now, a critical mass of young faculty members had joined the faculty and was impatient for change. Following the publication of his article, Mautner was appointed dean of the Tel Aviv Faculty of Law and has been credited with having consolidated the ascent of American influence. Under his leadership, more graduates of leading American law schools were hired, more curricular reforms were introduced, and more interdisciplinary scholarship was produced and published. Many agree that the 1990s were the time of the great leap forward, when Tel Aviv became an intellectual powerhouse on a par with any elite law school in the United States. ${ }^{100}$

Experience tends to cool fervent enthusiasm. Ten years later, Mautner modified his position in another article. As dean, he said, he came to recognize the need for the Faculty of Law to train lawyers, and therefore

\section{Id. at 28}

99 "In the decade prior to writing this article I spent considerable time in the United States as a student and then as a teacher. Every time I returned to Israel, I found myself frustrated because of the fact that things that were treated as givens in leading U.S. law schools were looked upon with suspicion, if not with actual delegitimation in the Israeli law schools." Menachem MAUTNER, On Legal EduCATiOn 5 (2002) (Hebrew) (this slim volume contains the two Mautner articles on legal education).

100 This is also the place to mention other energetic deans who participated in this process, from Uriel Reichman, who was dean in the 1980s (and went on to establish the formidable university called the Interdisciplinary Center in Herzlia (IDC)), to Ariel Porat, and presently Hanoch Dagan, who is building on these changes and taking the law school in new directions. See particularly the innovative graduate school developed by Dean Dagan. The Buchmann Faculty of Law, The Zvi Meitar Center for Advanced Legal Studies, http://www.law.tau.ac.il/Eng/?CategoryID=191 (last visited July 20, 2008).

As I noted earlier, some believe that there were two American moments, and that the moment of the 1990s should be seen as new and independent of the 1970s. See supra note 14. In my view, a rejection of the roots of the American moment in the 1970s, and the insistence that the 1990s were "totally new," is an example of the tension between memory and history. Mautner justly recalls the excitement and energy produced by his 1992 article, but his ability to publish in a new journal, and his invitation to present the work at various legal workshops across Israel, are themselves indications that legal education was following the American model, adopting such features as journals and workshops. 
the role of technical doctrine in the curriculum. He now suggested that law faculties legitimately divided into three groups: doctrinalists, theoreticians, and critics. He conceded the significance of the doctrinalists, and called for tolerance, dialogue, and mutual respect of one group towards the other. ${ }^{101}$

Ron Shapira, a colleague of Mautner's in the 1990s, and later dean of the Bar-Ilan Faculty of Law, responded with a critique of Mautner's thesis. Ron Shapira (to be distinguished from Amos, by now on the verge of retirement) focused primarily on Mautner's article, giving it an economic spin. Behind it, he argued, was an effort by law professors to create an interest group that would maintain a monopoly over the field of legal education, at the expense of lawyers and judges who had been an integral part of the pedagogic enterprise. Ron Shapira also defended formalist legal thought, challenging the thesis that it has been a failed jurisprudence:

Even before the new paradigm advocated by Mautner and Procaccia became dominant, it encountered an opposition in the form of those anxious to maintain the old doctrinal mode of legal research. ${ }^{102}$

Ron Shapira relied on Justice Antonin Scalia and Fred Schauer (both Harvard Law School graduates) to sustain his claim. Earlier in his article, he enlisted Judge Richard Posner (another Harvard Law School graduate) in support of his critique of the "policy-oriented" mode of legal analysis. Mere policy arguments, based on generalizations and unsupported by empirical verifications, he declared, were empty and barren, and only served to confuse legal analysis. ${ }^{103}$

Which brings us back to Dean Weisman. It was Dean Weisman who, in 1982, had issued the warning that Israelis should beware of importing the policy-oriented mode of legal instruction. Ron Shapira echoed Weisman and, like Mautner, did not situate the debate as a continuation of any particular Israeli historical tradition. There was, however, a glaring difference between Shapira and Weisman. Weisman had argued that Israel was fundamentally different from the United States, and painstakingly developed an eight-point list to persuade his audience that adoption of the policy-oriented pedagogy was ill advised. Ron Shapira's challenge to the "new (American) paradigm"

101 MAUTNER, supra note 99, at 91.

102 Ron Shapira, Menachem Mautner's On Legal Education, 27 IYUNEY MishPAT 821 (2004) (Book Review) (Hebrew).

103 Id. at 825 (note 6 and accompanying text, quoting RICHARD A. POSNER, PROBLEMATICS OF MORAL AND LEGAL THEORY (2002)). 
was based on a competing "old-new (American) paradigm," which was advanced by Scalia and Posner. ${ }^{104}$

The debate brings us back to Dean Weisman in yet another aspect, important for our subject matter: the intimate link between legal education and legal scholarship. The scholar's legal thought affects her teaching method. The call for interdisciplinary study ("law and ...") was becoming a part of Israel's landscape. Ron Shapira was not calling for a return to the frontal lecture model, and did not appear to be troubled by the changing structure of the Israeli law school.

From this perspective, the American moment appeared triumphant. In the 21 st century, all the participants in the Israeli debate were Americanized. ${ }^{105}$ As in the United States, there has been no resolution regarding the preferred legal theory. The debate as to whether law is a closed or open system is likely to occupy Israelis for many years to come, just as it occupies Americans. The difference between the late 1960s and the first decade of the 21st century is that today both Israelis and Americans draw water from the same intellectual well. As a result, for Israeli law students, the U.S. legal landscape is no longer "terra incognita."

$$
* * *
$$

All three basic features of American legal education - law reviews, curricular reforms, and a shift from frontal lectures to open discussions have taken root in Israel. Is it possible to call this turn of events a complete triumph of the American moment? I shall return to this question in my Conclusion, after a short discussion of some of the reasons for the strong influence of U.S. legal thought in Israel today. For now, as further reflections on transplantation, let me remind the reader that even though I claim that the American approach triumphed, Israeli legal education nevertheless appears to have retained its peculiar and authentic profile. The Israeli Faculty of Law reflects important aspects of Israeli culture, which are different from those of the United States. Israeli law students are not expected to have a

104 Of course there are fundamental differences between Scalia and Posner. Ron Shapira was relying on the similarities.

105 Still, this may not mean that the "culture of learning" in the Israeli law school mirrors the culture of learning in any elite American law school. For a devastating critique of the Israeli environment of legal learning, co-written by an eminent scholar well acquainted with the American, the European, and the Israeli legal cultures, see Joseph Weiler \& Yaniv Friedman, On The Education for Superficiality, 25 IYUNEY MishPAT 421 (2001) (Hebrew). 
college degree prior to enrollment in law school. Their teachers (at least at the Hebrew University and Tel Aviv University, which are state universities) earn roughly the same salaries as the professors at the faculties of Arts and Sciences. Grading is another important difference. Israeli law professors who teach mandatory courses do not grade their own exams. Similarly, Israeli law professors who teach electives do not grade their own exams if the class is sufficiently big. ${ }^{106}$ In this they resemble their European colleagues. To balance the prerogative of professors (which many American professors are likely to envy), Israeli students have a right to take the examination on two different dates, and they consider this right inalienable. ${ }^{107}$ The lesson, from the perspective of the theory of transplantation, is that certain elements of a system are so deeply embedded that their survival is practically predictable. Israeli legal thought owes much to the United States and feels at home in its milieu. And yet it is its own creature, the result of its own historical development, which is distinct from that of the U.S.

\section{Context: \\ ISRAEL AS A WILLING IMPORTER OF AMERICAN INFLUENCE, The United States as an ACTIVE Exporter}

So far, I have reviewed the migration of some of the cornerstones of American legal education into Israel by attributing the process to a few individuals: Aharon Barak, Itzhak Zamir, Amnon Rubinstein, Amos Shapira, and, in later generations, Uriel Procaccia, Uriel Reichman, Menachem Mautner, and many others. I should pause to add that a few women were also involved in this struggle, even though none obtained positions of formal power and influence. Frances Raday and Orit Kamir at the Hebrew University, and Irit Haviv-Segal and Leora Bilsky at Tel Aviv, were actively involved in promoting the "law and ..." movement. ${ }^{108}$ However, without the

106 See Weiler \& Friedman, supra note 105, text accompanying notes 18-19.

107 The two separate dates for taking an exam (moed aleph and moed bet), one soon after the end of the school year, and the other several weeks later, was a device invented to accommodate students who do military reserve duty. All students, regardless of whether they do military duty, benefit from this system. Another significant difference is the fact that in Israel legal education confers an undergraduate degree. The universities, in turn, require that candidates for tenure track positions at the law faculties have a Ph.D. or an S.J.D. Another difference is that clerkships are mandatory and take place at both judicial chambers and law offices. I am grateful to Yoram Shachar and Sandy Kedar for these points.

108 It is also interesting to note that three of these four women taught law and feminism, 
conditions to facilitate, even encourage these changes, all of these professors may well have failed. In what follows, I only too briefly suggest some of the external factors responsible for this project's success.

\section{A. The Courts}

The story must turn again to Aharon Barak, who, as a young postdoctoral fellow, returned to Israel in 1967 suffused with eagerness to transform his Faculty of Law into an elite institution, preferably modeled after the Harvard Law School. Barak was destined to serve in positions more versatile and powerful than the conventional law professor. From 1980 to 2006, he served as associate, and then as chief, justice of Israel's Supreme Court. He brought to the Court a different way of thinking about the law, and an interest in the relevance of American law. ${ }^{109}$ He used such doctrines as balancing and purposive interpretation in order to make Israeli decisional law less authoritarian and more liberal. Along the way, he also made it less formalistic. Utilizing two basic laws authored by Amnon Rubinstein (when Rubinstein served as a member of the Knesset), Barak launched a constitutional age in Israel, which invigorated the idea that Israel was not a pure majoritarian democracy, but rather a polity striving to honor political and civil rights and liberties, especially of minorities. Concepts such as freedom of expression, gender equality, gay rights, and more, became household terms in the Israeli legal discourse. ${ }^{110}$ The judicial opinions were integrated into the

and made a substantial contribution to the development of feminist consciousness in Israel and to introducing this mode of thought to students. See also Leora Bilsky, Cultural Import: The Case of Feminism in Israel, 25 IYUNEY MISHPAT 523 (2001) (Hebrew). Many others followed, e.g., Daphne Barak-Erez and Daphna Hacker.

109 Many are under the impression that the rate of Israeli judicial reliance on U.S. law has substantially increased over the last two decades. However, a statistical study conducted by Yoram Shachar and his co-authors, while conceding that the reliance on U.S citations has increased, still claims that the status quo has not been destabilized.. The study does not distinguish between canonical and ordinary cases. See Myron Gross, Ron Harris \& Yoram Shachar, Patterns of Citation at the Supreme Court: Quantitative Analysis, 27 MishPATIM 119 (1996) (Hebrew) (an update is forthcoming).

110 For an exposition of Barak's judicial philosophy, see AHARON BARAK, A JUDGE IN A DEMOCRACY (2006). Israeli law students coming to the U.S. since the late 1980s were puzzled by the strict construction and formalistic opinions emerging from the Rehnquist Court. They had no idea that what they thought of as "the different Israeli approach" was an approach characteristic of the Warren and Brennan Courts in the U.S. of the 1960s and 1970s, an approach which migrated to Israel under Chief Justices Meir Shamgar and Aharon Barak. It should also be 
curriculum and affected scholars, teachers, and students. This was another method by which U.S. law infiltrated Israeli thought. As might be expected, some of the faculty and students in the various law schools responded with enthusiasm, while others reacted with concern or alarm. ${ }^{111}$

\section{B. The Legal Profession}

The legal profession has also witnessed considerable change in the last two decades. Whereas the equivalent of the American law firm - large, bureaucratized, and regimented - barely existed in Israel in the 1950s and 1960s, the 1990s saw such firms proliferate, mainly due to the closer relationship with the United States (about which more momentarily), and the wish to maximize profits. ${ }^{12}$ A process of cross-fertilization must have taken place between the law schools and the legal profession in order to produce and facilitate this change. ${ }^{113}$

\section{The Privatization of Law Schools}

Since 1990, the number of law schools has proliferated. In 1967 there

mentioned that Barak never gave up his academic affiliations. He has been known for his annual visits to Yale Law School, where he either taught seminars or updated himself on cutting edge scholarship. He is currently a faculty member at the Interdisciplinary Center (IDC) in Herzlia.

111 See, e.g., Pnina Lahav, Israel's Supreme Court, in CONTEMPORARY ISRAEL 135 (Robert O. Freedman ed., 2008), and references therein.

112 See Shapira, supra note 102, at 826.

113 For example, Israeli law schools today not only compete for students, but also strive to place their graduates with the most prestigious firms, and then rely on this data to recruit more and abler students.

An article in The Marker, the daily Haaretz's financial magazine, titled Partners in the Heights of Manhattan, describes three graduates of the Tel Aviv Faculty of Law who made it to partnership in big New York firms. The article advises those who wish to follow suit to: (1) get an LL.M. from a prestigious American law school; (2) pass the bar examination in the relevant state; (3) get letters of recommendation from attorneys who are employed in the U.S. law firm, or from Israeli attorneys who are valued in the U.S.; (4) get letters of recommendation from American professors; (5) have past employment experience in a big Israeli law firm which has a working relationship with American firms; and (6) have specialization in areas relevant to Israeli companies which are active in the U.S. - intellectual property, mergers and acquisitions, and securities. The article also states that "in almost all the leading New York law firms today you will find at least one Israeli attorney." Partners in the Heights of Manhattan, ThE MARKer, Apr. 28, 2008, at 26. 
were two law schools situated inside two established universities; today there are ten law schools, six of which are in private hands. ${ }^{114}$ The idea of the private law school was pioneered simultaneously by Daniel Friedmann, who founded the School of Law at the College of Management in Rishon Le-Zion, and Uriel Reichman, who established the Interdisciplinary Center in Herzlia. Reichman's contribution to legal education in its broadest possible sense should be the subject matter of a separate tome. The idea of the private law school is itself American, and a quick look at the curricula of these schools confirms their pedigree. So too is the exponential rise in the number of law students. The expansion of the legal profession in Israel traces a similar phenomenon in the United States. ${ }^{115}$ One reason for the growing number of law schools in Israel is the fact that the university law faculties, particularly in Jerusalem and Tel Aviv, recognized their potential to become elite schools and raised the admission requirements. For a while, an entry ticket to one of these schools was so desirable that it was harder to gain admission to law school than to the highly competitive medical schools. Students who could not meet the admission criteria sought legal education abroad, particularly in England. The opening of more law schools diverted their tuition revenue back to Israel. ${ }^{116}$

The rising status of the legal profession, coupled with the increasingly privatized market in Israel, are symptoms of the watershed changes that Israel has gone through since the late 1960s, and are closely tied to

114 Of the private law schools, one should flag the Interdisciplinary Center, whose name alone discloses the wish to align Israel with the interdisciplinary approach to law, advocated in many American law schools. The IDC's founder, Uriel Reichman, emphasizes the link between business and technology, and encourages a strong nationalist and neo-liberal ideology for Israel. It is not surprising that he is a graduate of the University of Chicago Law School. The IDC, which pays its professors American salaries, is both competitive and successful in the Israeli academic landscape.

115 "Over 135,000 Law School Admissions Tests were administered in 197374 , up nearly $10 \%$ from the previous year and almost twice as many as during any year of the 1960s." Laura Kalman, Right Star Rising: American Politics and the Limits of Leadership, 1974-79 ch. 1 (unpublished monograph, on file with author). See also Jordan Miller, "Why Is Everyone Taking the LSAT?" A Model of the Demand for Law School 53 fig.1 (May 2004) (Honor Thesis, Stanford Univ. Dept. of Econ.), available at http://wwwecon.stanford.edu/academics/Honors_Theses/Theses_2004/Miller.pdf; An Awful Lot of Lawyers Involved, TIME, July 9, 1973, at 50.

116 The flood of new lawyers led the Bar to forego the traditional oral examination where passage was practically guaranteed, and introduce somewhat more rigorous written examinations. 
American influence on Israel in general. ${ }^{117}$ Furthermore, in the beginning, these law schools relied on the existing pool of law teachers from the already established schools, but they needed new blood and therefore signaled to excellent students interested in teaching law that slots were available. ${ }^{118}$ These students were encouraged and, one assumes, also personally inclined to study in the United States. Thus, between 2000 and 2006, 63 Israelis earned the S.J.D. degree from elite law schools in the United States, compared with only eight through the 1950s and 1960s. ${ }^{119}$ Inevitably, those graduates who returned to Israel with the knowledge and tools acquired in the United States were comfortable in applying what they had learned abroad. ${ }^{120}$

117 Gad Barzilai, The Ambivalent Language of Lawyers in Israel: Liberal Politics, Economic Liberalism, Silence and Dissent, in FIghting FOR POLITICAL FreEdom 247, 247-49 (Terence C. Halliday, Lucien Karpik \& Malcolm M. Feeley eds., 2008).

Barzilai observes:

[T]he number of lawyers during the years 1968 to 2005 has increased by 1552 per cent, while the population growth has increased by 246 percent. Accordingly, demography may explain [only] some of the growth in number of lawyers . . . . Most of the dramatic increase . . . was absorbed by legal departments in commercial banks, insurance companies, municipalities, and by the state attorneys general and general prosecutor offices . . . yet the private market of lawyers has noticeably been expanded as well. Since the late 1980s, as part of international capital flow into and from Israel, a phenomenon of mega law offices (law offices that have included several dozen lawyers) has been developed. Several law offices have established branches overseas, e.g., in London and New York City. Indeed, the Israeli economy has become more liberal and lawyers have been one major vehicle to incite it and to benefit from it.

Id. at 257.

118 For example, the law school at the College of Management was founded by Daniel Friedmann of the Tel Aviv Faculty of Law. The law school in Ramat Gan was established by the faculty of the Hebrew University. The law school in Netanya was established by members of the Bar-Ilan faculty.

119 I thank Gail Hupper for sharing this information with me. The schools included in Hupper's study are Columbia, Harvard, Michigan, N.Y.U., Wisconsin, and Yale. See infra note 131.

120 In comments on my paper, Celia Fassberg pointed to the irony that while the creation of the private law school reflects American influence, the culture in those schools may well reflect the culture prevailing in the law faculties in Jerusalem and Tel Aviv in the 1950s and 1960s. Fassberg, supra note 57. If this is correct, it probably mirrors the difference between elite and low-status law schools in the U.S. 


\section{Globalization/Americanization}

In the 1950s and 1960s, the self-image of Israelis was captured by a small, cartoonish figure called "Srulik" (a nickname for Israel), a childlike, rather innocent and vulnerable sabra. In 2004, Israeli sociologist Oz Almog published a two-volume book titled "Farewell to Srulik." The cover said it all: on it appeared little Srulik, still wearing sandals, but with something new printed on his shirt: an American flag. ${ }^{121}$ Almog was describing the process through which Israel abandoned its erstwhile socialist, idealist, and rather autonomous culture, and joined the worldwide processes of Americanization and globalization. ${ }^{122}$

Globalization barely needs elaboration. Israel has taken an active part in this trend in almost every field and corner of its being. Structural economic changes as well as far-reaching social and cultural changes have swept the land since the 1980s. Israel as a welfare state was replaced by a Reaganist (or Thatcherist) version of economics. American political advisors were hired to guide commercialized election campaigns; shopping malls and branches of McDonalds sprang up everywhere, and the media fell into the habit of imitating the predominant trend in American popular communications. ${ }^{123}$ These trends affected the legal community. Lawyers, says political scientist Gad Barzilai,

became more engaged in politics as agents of liberal economy and have significantly contributed to the economic liberalisation of the state and afterward to its interactions with the global economy. Economic privatization of currency, financial institutions, governmental agencies, public services, and the labour market has altered the basic relationship between state power foci and lawyers, since the liberal maze

121 Oz Almog, Farewell to "Srulik": Changing Values Among the Israeli ELITE (2004) (Hebrew).

122 See also Andras Jakab, Dilemmas of Legal Education: A Comparative Overview, 57 J. LEGAL EDUC. 253 (2007) (discussing the complex meaning of legal education in a globalized age); and Laurel S. Terry, The Bologna Process and Its Implications for U.S. Legal Education, 57 J. LEGAL EDUC. 237 (2007) (discussing the need of American legal education to address changes brought about by the requirements for more uniformity in education developed by the European Union).

123 For analysis as well as exposure of the dialectics involved in these trends and the political and social powers pulling in the opposite direction, see URY RAM, THE GLOBALIZATION OF ISRAEL: MCWORLD IN TEL AVIV, JiHAD IN JERUSALEM (2007), and references therein. See also GUY MUNDLAK, FADING CORPORATISM: ISRAEL'S LABOR LAW AND INDUSTRIAL RELATIONS IN TRANSITION (2007). 
of economic transactions requires the veil of certainty that legal knowledge may provide. ${ }^{124}$

A direct cause-and-effect relationship between these trends and American influence on Israeli legal education is hard to document, but there does seem to be a correlation. ${ }^{125}$ The more Americanized and globalized Israel becomes, the more its institutions are likely to resemble institutions in the United States.

\section{E. Foreign Affairs}

Israel has perceived itself as being, and in many ways has indeed been, isolated in the world. Until the 1967 war, its main ally was France. France gave Israel the weapons it needed to feel secure, and France helped Israel build its nuclear plant in Dimona. However, while the strong relationship with France did yield extensive cultural ties, it failed to influence the legal system. It is thus another lesson in transplantation, and a warning not to get carried away by appearances of collaboration. Language must have been a formidable barrier. French was taught in Israeli high schools as an elective, while English has always been required. The dominant role of English has certainly been felt in the law schools, where some proficiency in English was essential. ${ }^{126}$ Of course, the history of the British Mandate in Palestine and the strong influence of the common law system also have played a dominant role. Until the 1970s, this English dominance over Israeli law, coupled with the generous grants distributed by the British Council (which have dwindled since the Thatcher era), made elite English universities particularly attractive to Israelis. ${ }^{127}$ However, the United States was destined to take center stage. From Israel's beginnings, and despite the strong French Connection, Israel's leadership aspired to align itself with the United States. ${ }^{128}$ In the 1950s and 1960s, Israeli prime ministers courted the United States and tried to curry

124 Barzilai, supra note 117, at 255.

125 See Kennedy, supra note 89. His stages of the globalization of law correspond to the stages described in this Article.

126 Today, many of the visiting professors coming to Israel to teach crash courses teach in English, but it is hard to imagine a class conducted in French.

127 Thus, for example, Yoram Shachar, a leading Israeli legal historian and a scholar versed in the "law and ..." movement, pursued his graduate work at Oxford because of such scholarship. Interview with Yoram Shachar, supra note 46.

128 See, e.g., Elizabeth StePhens, U.S. Policy TOWARDS ISRAEl: The Role of Political Culture in Defining the SPecial Relationship (2006). For an interesting analysis of the formation of law in Mandatory Palestine, see ASSAF LikHOVSKI, LAW AND IDENTITY IN MANDATE PALESTINE (2006). 
favor with its presidents and its congressional leadership. This was an uphill battle, as the United States, anxious about the Cold War and battling the Soviet Union for hegemony in the Middle East, was not keen on putting too many eggs in the Israeli basket. For a variety of reasons that will not be reviewed here, 1967 proved to be a watershed year. The fact that France snubbed Israel at precisely the moment that Israel was experiencing dire existential peril was also critical. American presidents from Lyndon Johnson to Ronald Reagan and William J. Clinton showed increasing sympathy toward Israel. ${ }^{129}$ Since the 1980s, the support given by the U.S. Congress has been extraordinary. It is not surprising that Israeli academics, legal scholars included, have been attracted to the empire that bestowed so much support upon their country. No one should underestimate the power of feeling loved and appreciated; it may even affect as dry a matter as the model of legal education.

After 1967, Israel accelerated its own military defense and defense industries, and this effort, coupled with gigantic purchases of arms from the United States, tilted the balance decisively. Much of the high-tech boom in Israel is due to Israel's military industrial complex, and rooted in the early 1970s. The eagerness of its business community to intensify the ties with the United States has been clear throughout these years. In many ways, Israel has become a client state of the United States, inevitably opening its gates to more and more American influence. The Americanization of Israel has been intensively documented. Universities and law schools could not have nor wished to escape it. The best proof is the American components present at the faculties of law in Jerusalem and Tel Aviv, as described in my Preface.

\section{F. A View from the Other Side: The Cow and the Baby Calf}

The Talmud observes that "more than the calf wishes to suck, the cow desires to suckle." 130 How did the United States contribute to the developments described above? I wish only briefly to offer some suggestions. Gail J. Hupper has shown that in the late 20th century, American law schools, particularly the elite law schools, were quite active in training foreign lawyers and academics and exporting the American legal culture

129 In 1958, U.S. Secretary of State John Foster Dulles declined Israel's government invitation to attend the celebration of its 10th Anniversary. No one fantasized that President Dwight D. Eisenhower might attend. In 2008, President George W. Bush found time in his busy schedule to honor Israel with a special visit as it celebrated its 60th Anniversary.

130 Babylonian Talmud, Pesachim 112a. I thank Hanina Ben Menachem for helping me locate this saying. 
abroad. ${ }^{131}$ Hupper even goes as far as to note the particular case of Israel. American wealth, grants, scholarships, and attractive learning environments have attracted foreign graduates, among them Israelis. ${ }^{132}$ LL.M. and S.J.D. programs in American law schools have expanded, even proliferated. These programs generate tuition for the American law schools and enhance their prestige abroad, an important asset in our age of globalization. Exchange programs between American law schools and sister schools abroad have become an attractive feature of the J.D. program, thereby further encouraging the presence of American law abroad. Thus, America has done its share to lure and influence the foreign law graduate, thereby increasing its influence, prestige and business profits. Israelis are merely one segment of a general trend of foreigners studying in the U.S. and returning to share their acquired knowledge with the professionals at home.

The Jewish factor may also be relevant. After the 1967 war, Israel's prestige in America was ascendant. Again, I am only talking of general impressions, but it is not farfetched to assume that the large Jewish presence in American law faculties and leading law firms bred extra sympathy toward the Israeli legal professional, student, faculty member, and attorney. The brilliance of the Israeli graduates, and their eagerness to absorb the American way, may have been matched by the eagerness of the American Jewish law professors to facilitate their integration and to get closer to Israeli culture. One should not be surprised to discover that this has been an instance of the proverbial "marriage made in heaven."

\section{NOTHING LASTS Forever: Which WaY Is THE Wind BLOWING?}

The reader is aware of the fact that some of my data comes from interviews with persons who were influential at one or another critical step of the process of shaping the Israeli law school on the lines of the American model. These

131 Gail J. Hupper, The Academic Doctorate in Law: A Vehicle for Legal Transplants?, 58 J. LEGAL EDUC. 413 (2008). Hupper found that close to half of the faculty of law at Tel Aviv hold an American S.J.D. degree, compared with close to $25 \%$ at the law school of the National Taiwan University, and $17 \%$ at Seoul National University. Id. at 415. For further specific discussion of Israel, see id. at 448. Still, U.S. legal education itself may have to go through changes because of the Bologna Process now being implemented in Europe. See Terry, supra note 122.

132 Simultaneously, the budget of the British Council, which has financed many Israeli graduates over the years, appears to have shrunk. 
interviews have yielded an additional and interesting insight: many pointed out that in their opinion the ground has been shifting. Europe, particularly Germany, has become more attractive to Israeli scholars and educators. ${ }^{133}$ The meaning of this shift, if indeed it is one, is not yet clear, as it appears to be in its initial stage. Some opined that German scholarship today, or European Community scholarship, is more interesting and relevant to Israel. Some said that the brutal dominance of market forces in the United States has turned them off, and that they were looking for legal alternatives in Europe. Others reported that the contentious faculty relations in the United States, particularly at Harvard Law School, have affected them negatively and made them look elsewhere. It may well be that European or, more specifically, German grants and scholarships have something to do with the new romance. Another trend worth noting is the growing Israeli interest in Asia. There is evidence of collaboration between Israeli law faculties and sister schools in China, India, and South Korea. ${ }^{134}$ This trend reflects the Israeli economic interest in these countries, as well as international developments. Another factor, not to be underestimated, is that many countries have undergone Americanization simultaneously, and therefore Israelis find a common language with Koreans or Japanese - the language acquired in U.S. law schools. ${ }^{135}$ Only time will tell how these ties change the face of the Israeli Faculty of Law.

Another reason may be the maturity of the Israeli legal academy. Confidence in itself and in its path may enable it to look more critically and soberly at what America has to offer, ${ }^{136}$ and allow it also to connect to its deeper roots and see that some of the gold that appeared to glitter so seductively when the Israelis came to the American elite law school had actually been lying around Israel itself. After all, sociological jurisprudence or interdisciplinary

133 See most recently Kristoffel R. Grechenig \& Martin Gelter, The Transatlantic Divergence in Legal Thought: American Law and Economics v. German Doctrinalism (U. of St. Gallen Law \& Economics Working Paper No. 25, 2008), available at http://SSRN.Com/abstract=1161168, arguing that German legal thought has been resistant to U.S. law, and to law and economics in particular. Thus there may be a correlation between the Israeli [re]turn to Europe and the German rejection of U.S. legal thought.

134 Interview with Hanoch Dagan in Tel Aviv (Feb. 2, 2008).

135 See Fassberg, supra note 57. Note too that law schools in Asia may have a common language with Israel. Many have intellectual legal roots in Europe, and faculty who hold S.J.D.s from elite law schools. See Hupper, supra note 131, at 415. See also Leigh Jones, Foreign Law Schools Follow the U.S. Playbook, NAT'L L.J. ONLINE (Sept. 2008), http://www.nlj.com. I thank Professor Frances Miller for directing me to this source.

136 Interview with Hanoch Dagan, supra note 134 
study were discussed in Israel as early as the 1930s by European immigrants who founded the Higher School for Law and Economics in Tel Aviv. These scholars were rejected by the professors at the Hebrew University Faculty of Law, who were disciples of the "law as science" tradition. It should not be surprising to learn that these old European roots of Israeli legal education somehow stir the legal imagination, and that while the old controversy may change garb, it yet has the quality of a déjá vu. The turn of de-Americanization, if a turn it is, is something to observe and follow before any solid conclusions may be drawn. Ironically, scholarship on American legal education has itself excavated the European, more specifically German, roots of the academic law school in the United States. ${ }^{137}$ Asian legal systems also owe a debt to continental Europe. Thus, we may all be Americanized, but it is also quite possible that deep down inside, we are all continentalists of one sort or another.

\section{Conclusion}

The history of the Israeli Faculty of Law displays an increasing reliance on the American model of legal education. Since 1967, the Israeli Faculty of Law has adopted the pillars of American legal education: a student-run law review, a curriculum based on a small core of mandatory courses and a large number of electives and seminars, a lively teaching method which engages the students, legal clinics, moot courts, workshops, and even the job-talks so familiar in the American legal landscape. The debate over what law is - the intellectual tension between such theories of law as law and economics, law and sociology, and law and culture, between law as a closed system of rules as distinct from a "law and ..." approach — is as lively in Israel as it is in the United States. But while conceding the power of the American influence, one should resist the temptation to see these developments as mindless imitations. Most of the young students who went to the United States and returned to Israel equipped with legal knowledge were capable of absorbing knowledge through a critical lens. The skepticism they encountered also made a difference. The result has been institutions which walk the walk and talk the talk of American legal culture, but still retain autonomy and a

137 Laura I. Appelman, The Rise of the Modern American Law School: How Professionalization, German Scholarship, and Legal Reform Shaped Our System of Legal Education, 39 NEw ENG. L. REV. 251 (2004); and Kennedy, supra note 89. 
distinct identity. As this Article is being written, they may be poised to once again reinvent themselves in order to better face the 21 st century.

In conclusion, and by way of evaluating the degree of Americanization experienced by the elite Israeli law schools, it seems wise to recall the purpose of a law school or law faculty wherever they may be. Legal Historian Robert Gordon, in discussing the intellectual history of the Yale Law School, suggested that a law school is similar to a rubber band, "which acts perpetually to drag the more adventurous experiments with legal education and the role of the law teacher back into the narrow confines of a set of basic routines - the private law-centered, doctrinecentered, court-centered, case-centered curriculum, which accepts existing legal arrangements as given, and subject to only minor modifications." 138 Law school, according to this metaphor, is technical and doctrinal at its core, with an essence that cannot and will not be compromised. Legal intellectuals everywhere, in New Haven, Tel-Aviv, Berlin, or Mumbai may try to stretch that rubber band and may even succeed. But sooner or later, the "pull" will restore the balance between law as a multidisciplinary field of study and law as a technical and doctrinal system of rules. In the late 20th and early $21 \mathrm{st}$ centuries and outside of the United States, the stretching of that rubber band amounted to American moment[s].

138 Gordon, supra note 76. 
